American University Washington College of Law

Digital Commons @ American University Washington College of

Law

Articles in Law Reviews \& Other Academic

Journals

Scholarship \& Research

2020

\title{
The Lost Unfair Competition Law
}

Christine Farley

American University Washington College of Law, cfarley@wcl.american.edu

Follow this and additional works at: https://digitalcommons.wcl.american.edu/facsch_lawrev

Part of the Intellectual Property Law Commons

\section{Recommended Citation}

Farley, Christine, "The Lost Unfair Competition Law" (2020). Articles in Law Reviews \& Other Academic Journals. 1846.

https://digitalcommons.wcl.american.edu/facsch_lawrev/1846

This Article is brought to you for free and open access by the Scholarship \& Research at Digital Commons @ American University Washington College of Law. It has been accepted for inclusion in Articles in Law Reviews \& Other Academic Journals by an authorized administrator of Digital Commons @ American University Washington College of Law. For more information, please contact kclay@wcl.american.edu. 


\section{The Trademark Reporter}

THE LOST UNFAIR COMPETITION LAW

By Christine Haight Farley*

\section{Table of Contents}

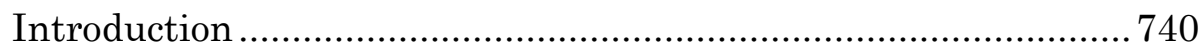

I. Unfair Competition Law's Enduring Uncertainty ..................... 743

II. The Original Unfair Competition Law ................................... 746

A. The Former Constraints on Trademark Law .................. 747

B. The Growth of Unfair Competition Law......................... 749

III. The Singular Contributions of Edward Rogers ....................... 755

IV. The 1929 Inter-American Trademark Convention.................. 758

A. The Convention's Innovative Text .................................. 760

B. Unfair Competition in the Inter-American

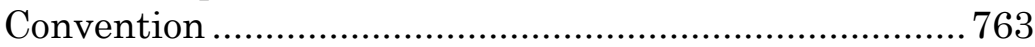

C. The Inter-American Convention Today …….................... 768

V. The Death of Common Law Unfair Competition ...................... 771

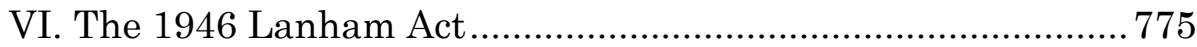

A. Legislative History Lessons ……………........................ 778

B. The Intent of Section 44 .............................................. 780

C. The Drafting Choice Made by Rogers ............................... 784

VII. The Revival of Unfair Competition under Section 43(a) ...... 788

VIII. The Unbeaten Path .......................................................... 794

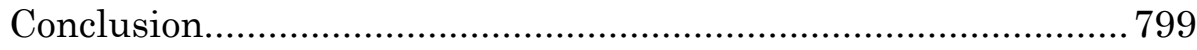

Professor, American University Washington College of Law, Member, International Trademark Association. I am grateful for the excellent research assistance provided by Meredith Bayer, Ben Kessler, and Sherwet Witherington, and for the insightful comments by Barton Beebe, Robert Bone, Rochelle Dreyfuss, Jake Linford, J. Thomas McCarthy, and Rebecca Tushnet. 


\section{INTRODUCTION}

The development of these rules now defined as 'Unfair Competition,' is one of the romances of legal history. $\sim$ Harry D. Nims, Unfair Competition and Trademarks ${ }^{1}$

There may be no term in all of intellectual property law as slippery as "unfair competition." It is a common refrain that trademark law "is but a part of the broader law of unfair competition." 2 Certainly this implies legal protection beyond what is protected by trademark law. But what is it? And where is it? Ask ten trademark lawyers to identify the protections offered by unfair competition law and you could get ten different answers, but more likely, you will get a shrug from half the respondents. ${ }^{3}$

Lost in history and buried in the interplay between the United States Trademark Act of 1946 (the "Lanham Act") and a particularly innovative treaty lies a clear answer to the question "What is actionable unfair competition?" This article explains why we have lost sight of this answer and become confused about the scope of unfair competition law today by providing a historical examination of the drafting and enactment of the act and mysterious treaty, and their forgotten connection.

Tracing unfair competition law's erratic development, this article recovers forgotten history. Unfair competition law underwent significant common law expansion in the decades before the Great Depression, reaching a high point in protection in International News Service v. Associated Press in 1918. ${ }^{4}$ The timing of the Supreme Court's decision in Erie Railroad Co. v. Tompkins in 1938, which purported to overturn all of the federal common law,

$1 \quad$ Harry D. Nims, Unfair Competition and Trademarks 2 (3d ed. 1929).

2 See, e.g., American Steel Foundries v. Robertson, 269 U.S. 372, 380 (1926) ("The law of trade-marks is but a part of the broader law of unfair competition.”); United Drug Co. v. Rectanus Co., 248 U.S. 90, 97 (1918); Hanover Star Milling Co. v. Metcalf, 240 U.S. 403, 413 (1916); Walgreen Drug Stores, Inc. v. Obear-Nester Glass Co., 113 F.2d 956, 961 (1940); William M. Landes and Richard A. Posner, The Economic Structure of Intellectual Property Law 166 (2003). The statement that trademark law is a species of the genus that is unfair competition is also repeated. See Int'l Order of Job's Daughter v. Lindeburg \& Co., 633 F.2d 912, 915 (9th Cir. 1980) ("In general, the common law has been understood as protecting against the broad business tort of 'unfair competition' . . . [t]rademark infringement is a species of this genetic concept."); J. Thomas McCarthy, McCarthy on Trademarks and Unfair Competition § 2:7 (5th ed. 2019) (citing S. Rep. No. 1333, at 4 (1946)).

3 See, e.g., McCarthy, supra note 2 , at $§ 1: 8$ ("Can the tort of unfair competition be defined? The honest answer is no-not in the abstract. It is no easier and no more productive of practical results to define generally the exact limits of unfair competition than it is to define the exact limits of what is a 'tort' or a 'civil wrong."').

4248 U.S. 215 (1918); Harry D. Nims, Unfair Competition and Trade-Marks viii (2d ed. 1917) (“[Unfair competition law] is still in its infancy.”). 
was therefore momentous. ${ }^{5}$ At that point, most of unfair competition law had been developed by the federal courts. At this same time, bills that would ultimately become the Lanham Act ${ }^{6}$ were being debated in Congress. Given this timeline, it is then perplexing that those bills were not amended to include federal unfair competition claims. As this article will reveal, what was ultimately enacted were enigmatic provisions meant to indirectly create federal unfair competition protection.

The Lanham Act's legislative history reveals a disinclination to create a federal unfair competition cause of action. ${ }^{7}$ This legislative history offers the first clue, as of yet unexamined, as to how certain statutory provisions could nonetheless afford traders expanded unfair competition protection. This article will expose the potential of those provisions - still in place today-and explain how they have come to be overlooked.

One individual's contributions shed new light on unfair competition in the act. Edward S. Rogers, generally credited with drafting the Lanham Act, played an outsized role in the development of unfair competition law. He revised his draft act from 1920 until 1946. During that period, he was one of a few people responsible for the text of the chapter on unfair competition in the 1929 General Inter-American Convention for Trademarks and Commercial Protection ("Inter-American Convention"), ${ }^{8}$ a treaty still in force. These provisions are the most comprehensive treatment on the subject to date. ${ }^{9}$ Rogers also argued and won a Supreme Court case declaring the treaty to be self-executing. ${ }^{10}$ Congress passed the Lanham Act just six years after this ruling with language pointing to that treaty. ${ }^{11}$ With this timeline in mind, one can read the provisions on unfair competition in the Lanham Act with newfound perspicuity.

It would be an understatement to say that the Inter-American Convention is neglected in the literature on U.S. unfair competition

304 U.S. 64 (1938).

$6 \quad$ Pub. L. No. 79-489, 60 Stat. 427 (1946) (codified as amended at 15 U.S.C. $§ 1051-1129$ ).

7 See infra Part VI(A).

8 General Inter-American Convention for Trade-mark and Commercial Protection, Feb. 20, 1929, 46 Stat. 2907, 124 L.N.T.S. 357 [hereinafter Inter-American Convention]. The convention is referred to as both the "Inter-American Convention" and the "Pan American Convention" in this country, and the "Washington Convention" in Latin America. The convention entered into force in the United States on February 17, 1931.

$9 \quad$ See Walter J. Halliday, Inter-American Conventions for Protection of Trade-marks, 32 J. Pat. Off. Soc'y 661, 665-66 (1950) (mentioning Rogers and how the Convention was said to surpass the achievements of the Paris Convention by not only binding each country with respect to trademarks, but also to the repression of unfair competition).

10 Bacardi Corp. of America v. Domenech, 311 U.S. 150, 161 (1940).

11 The United States Trademark (Lanham) Act of July 5, 1946, Pub. L. No. 79-489, 60 Stat. 427 (codified at 15 U.S.C. $\S \S 1051-1127$ ). 
law. It is this convention, however, that contains the unfair competition law that was meant to be applicable today, but which has since been lost. The background of this convention tells a story of how Rogers was able to shape international treaties and federal statutes in a manner that could have yielded a dramatic expansion of unfair competition protection. Instead, Rogers's approach proved to be too radical a change in actionable claims, and too subtle a vehicle for such change; Rogers's vision of unfair competition never came to pass. As a result, Section 43(a) slowly began to fill the void that was left. That development, which has been haphazard, persists today. Cases like Belmora LLC v. Bayer Consumer Care $A G,{ }^{12}$ in which foreign trademark owners have successfully pressed claims of unfair competition in the United States, is part of this ongoing saga.

Part I identifies the confusion about the scope of unfair competition law that exists today. Part II traces unfair competition law from the beginnings of U.S. trademark law in the late 1800s to the 1946 Lanham Act. This section demonstrates that unfair competition law cropped up as a means to fill gaps in protection left by trademark law's constrained reach, not as a body of law subsuming trademark law. Part III tracks Edward Rogers's contributions to the international and domestic development of unfair competition law. Part IV describes the pioneering protection of unfair competition provided by the Inter-American Convention. Part V discusses how the emergence of the Erie Doctrine in the late 1930s threatened to create a void because state laws on trademark and unfair competition were underdeveloped compared with federal law. Part VI interrogates the history of Section 44 of the Lanham Act, demonstrating that it was meant to incorporate by reference the unfair competition provisions from Inter-American Convention. This section describes how the robust unfair competition protection enabled through Section 44 continues to lie dormant, and Part VII recounts how Section 43(a) instead emerged as the vehicle for unfair competition. As a result, Section 43(a) has been dramatically expanded while unfair competition law, as a distinct area, remains underdeveloped and continues to be undefined. Finally, Part VIII will offer some suggestion about how, in light of this history, the unfair competition law that was lost might be reclaimed.

12819 F.3d 697 (4th Cir. 2016) (allowing a $§ 43($ a) claim by the owner of a Mexican trademark that had neither used, registered, nor advertised the mark in the United States against the U.S. registrant of the same mark for the same goods where the Mexican mark had a reputation in the United States). 


\section{UNFAIR COMPETITION LAW'S ENDURING UNCERTAINTY}

Unfair competition law has always been baffling. It is perverse then that it is ever-present; in almost all trademark litigation, complaints include supplementary claims of unfair competition. ${ }^{13}$

Some think unfair competition protection is narrowly centered on certain misrepresentations made actionable by Section 43(a) of the Lanham Act. ${ }^{14}$ Under this view, unfair competition is composed of infringement of unregistered marks ${ }^{15}$ and certain claims of false advertising ${ }^{16}$ and is not very broad at all.

Even this narrow view of unfair competition remains uncertain as to scope, as a recent case exposed. In Belmora, the central issue was the extent of Section 43(a)'s unfair competition protection in the absence of a protectable mark. ${ }^{17}$ One may wonder how such a staggeringly basic question could still be unclear fifty years after passage of the Lanham Act. The way the case was litigated, ${ }^{18}$

13 Complaints often include supplementary unfair competition claims, some under federal law, and some under state law. These claims, however, are rarely resolved, as they usually serve as a backup to trademark infringement claims.

14 The Lanham Act, as amended, § 43(a), 15 U.S.C. § 1125(a) (2018).

$15 \quad$ See McCarthy, supra note 2, at $\S 4: 6$. Confining unfair competition to passing off, Judge Learned Hand stated: "The law of unfair trade comes down very nearly to this . . that one merchant shall not divert customers from another by representing what he sells as emanating from the second. This has been, and perhaps even more now is, the whole Law and Prophets on the subject, though it assumes many guises." Yale Electric Corp. v. Robertson, 26 F.2d 972, 973 (2d Cir. 1928). Justice O'Connor offered a similarly narrow conception on unfair competition: "its general concern is with protecting consumers from confusion as to source.” Bonito Boats, Inc. v. Thunder Craft Boats, Inc., 489 U.S. 141, 157 (1989).

16 Lanham Act $\S 43(\mathrm{a})(1)(B), 15$ U.S.C. $\S 1125(\mathrm{a})(1)(\mathrm{B})$.

$17 \quad 819$ F.3d 697.

18 Likely because there was no certain path to success, the plaintiff waited almost three years to take legal action even as the defendant used the mark and filed for registration. The plaintiff never opposed the defendant's application to register the mark, and when the plaintiff finally did take action, it attempted to cancel the registration rather than enjoin the use of the mark. See Prosecution History, USPTO, https://tsdr.uspto.gov/ (search for 78310029 in search bar) [https://perma.cc/WF2K-88XP] (last visited July 17, 2020). Even then, the plaintiff struggled to find a ground on which to base its claim. See Petition for Cancellation, Bayer Consumer Care AG v. Belmora LLC, Cancellation No. 92047741 (filed T.T.A.B. June 29, 2007). Reading its pleadings-twice amended following dismissals — one is left with the impression of a claimant flailing in desperation to land on a cognizable claim. The plaintiff asserted claims under three international treaties-unusual in itself in such proceedings, two of which were not even ratified by Mexico. See Bayer Consumer Care AG v. Belmora LLC, 110 U.S.P.Q.2d 1632 (T.T.A.B. 2014); Amended Petition for Cancellation, Bayer Consumer Care AG v. Belmora LLC, Cancellation No. 92047741 (T.T.A.B. Sept. 17, 2007); Second Amended Petition for Cancellation, Bayer Consumer Care AG v. Belmora LLC, Cancellation No. 92047741 (T.T.A.B. Aug. 28, 2008). 
arguments made in the case, ${ }^{19}$ and the commentary about the case, ${ }^{20}$ all illustrate the continuing lack of clarity about the boundaries of Section 43(a)'s unfair competition protection.

A contrasting position is that unfair competition goes well beyond source confusion and false advertising and provides an umbrella under which a broad number of disparate deceptive trade practices reside. The most expansive understanding of unfair competition defines unfair competition simply as any unfairness or inequitable conduct in trade. ${ }^{21}$

19 During oral argument when the appellee emphasized that the plaintiff had no protectable mark, the court asked, "What's that got to do with a passing off case?" Oral Argument, Belmora, LLC. v. Bayer Consumer Care AG, 819 F.3d 697 (4th Cir. 2016) (No. 15-1335), http://coop.ca4.uscourts.gov/OAarchive/mp3/15-1335-20151027.mp3. Only because the plaintiff had no protectable mark, the court explicitly asked the petitioner, "are we able to give you relief under 43(a)?" Id.

20 See, e.g., Brief for International Trademark Association as Amici Curiae Supporting Petitioners at *5, Belmora LLC v. Bayer Consumers Care AG, 137 S. Ct. 1202 (No. 16548) (2017) ("The Fourth Circuit's decision in Belmora . . . adds another variation to the already confusing array of holdings."); Barton Beebe, What Trademark Law is Learning from Right of Publicity, 42 Colum. J.L. \& Arts 389, 394 (2019) ("The [opinion in Belmora] further suggests that the language of section 43(a) refers to any entity in the world, regardless of whether it is actually using a trademark within the territorial borders of the United States. In sum, what is conventionally recognized as one of the fundamental distinctions between trademark law and right of publicity law - that the former requires a showing of consumer confusion while the latter does not-has arguably become a distinction without a difference."); Christine Haight Farley, No Trademark, No Problem, 23 B.U. J. Sci. \& Tech. L. 304 (2017); Mark P. McKenna \& Shelby Niemann, 2016 Trademark Year in Review, 92 Notre Dame L. Rev. Online 112, 122 (2016) ("But what is especially notable about Belmora is its failure to recognize the implications of its decision for the territoriality of trademark rights. Few concepts are more fundamental in trademark law than the notion that rights are territorial in nature."); Marty Schwimmer and John Welch, U.S. Law Inches Towards Protecting Trademark Reputation Without Use, World Trademark Review, Autumn 2019, at 78.

21 See, e.g., Telecom Int'l Am. Ltd. v. AT\&T, 289 F.3d 185, 198 (2d Cir. 2001) (the "law of unfair competition is a 'broad and flexible doctrine that . . . has been broadly described as encompassing any form of commercial immorality, or simply endeavoring to reap where one has not sown."') (quoting Roy Export Co. Establishment v. CBS, Inc., 672 F.2d 1095, 1105 (2d Cir. 1982)); see also Harry D. Nims, The Law of Unfair Business Competition (1909) ("it is an equitable rule that no unfair methods in business competition shall be allowed.”); McCarthy, supra note 2, at $\S 1: 9$. The Restatement of Unfair Competition includes "appropriation of intangible trade values including trade secrets and the right of publicity,' as well as "other acts or practices of the actor determined to be actionable as an unfair method of competition." Restatement (Third) of Unfair Competition $\S 1$ (Am. Law Inst. 1995). Throughout the four editions of Harry Nims's treatise on the subject spanning 1909 to 1947, Nims included materials on trade secrets, interference with contracts, and commercial disparagement. Nims (4th ed. 1947). The first edition was titled "The Law of Unfair Business Competition," but by the final edition, Nims had changed the title to "The Law of Unfair Competition and Trademarks." Nims (1st ed. 1909); Nims (4th ed. 1947). Other claims sometimes organized under the umbrella of unfair competition include bait and switch selling, sending baseless cease and desist letters, filing baseless litigation, business defamation, inducing breach of contract, and predatory pricing. See also McCarthy, supra note 2, at § 1:10; Zecharia Chafee, Jr., Unfair Competition, 53 Harv. L. Rev. 1289 (1940); Daniel M. McClure, Trademarks and Unfair Competition: A Critical History of Legal Thought, 69 TMR 305, 306 (1979). 
This article will address the distance between these understandings of unfair competition law and reveal why this uncertainty persists. In recounting certain episodes in the history of unfair competition law-some that have been forgotten and some never before revealed - this article affords greater clarity on unfair competition law and a new perspective on the relationship between unfair competition law and trademark law.

This article challenges conventional beliefs about the relationship between trademark law and unfair competition law. Recovering these episodes and piecing together timelines, this legal history reveals that unfair competition law did not beget trademark law, ${ }^{22}$ but the reverse. ${ }^{23}$ Unfair competition was developed as a gap filler for trademark law. The dominant notion today that trademarks are only a part of the larger area of law of unfair competition incorrectly suggests otherwise.

This mistake conceals the muddled relationship between trademark and unfair competition law, ${ }^{24}$ as well as the cloudy provenance of the latter. The idea of unfair competition being the genus or larger category within which we find the specific law of trademarks suggests that there is a defined category of protections that is more expansive than trademark law. But this category has never been defined in U.S. law; its boundaries have never been properly demarcated and its location has never been fixed. At no point was unfair competition so systematically formed as to spin off another set of common law rights, and in any event the origin of unfair competition law in the United States is more recent than trademark law. ${ }^{25}$ Although U.S. trademark law dates back to the mid-19th century, ${ }^{26}$ unfair competition law developed slightly later out of the gaps in protection in trademark law.

22 See, e.g., John M. Fietkiewicz, Section 14 of the Lanham Act-FTC Authority to Challenge Generic Trademarks, 49 Fordham L. Rev. 437, 440 (1981) (incorrectly stating that "[t]rademark protection evolved from the common law of unfair competition.").

23 See Frank I. Schechter, The Historical Foundations of the Law Relating to Trade-Marks 4 (1925) ("when we remember that out of the so-called law of technical trademarks has grown the law of unfair competition").

24 The genus-species metaphor is problematic here. It implies that trademark law is in a taxonomic rank subsumed by and shares an essential feature with unfair competition law much like donkeys are subsumed by the equus genus, being odd-toed ungulates with slender legs, long heads, relatively long necks, manes, and long tails. See generally Univ. of Mich. Museum of Zoology, Animal Diversity Web, https:/animaldiversity.org/ accounts/Equus/ (last visited Nov. 7, 2019). The metaphor therefore should beg the question: What is the family of unfair competition? Unfair competition was categorized as torts in the Restatement of Torts in 1938 whereas early trademark law was thought to be within property law.

25 See Nims, supra note 1, at 1-12 (summarizing the legal doctrine of unfair competition).

26 It was not until the end of the industrial revolution that trademark law began to flourish. See Schechter, supra note 23, at 143-45. 


\section{THE ORIGINAL UNFAIR COMPETITION LAW}

The first common law protection for trademarks was extremely limited. These protections developed into formalized rules protecting "technical trademarks" - those that could eventually be registered. ${ }^{27}$ What later became known as "unfair competition" was the protection of a limited set of unregistrable ${ }^{28}$ symbols referred to as "trade names." 29 Trade names consisted of descriptive words, geographical names, and surnames consistently used by traders. ${ }^{30}$ This protection of trade names was initially the full extent of unfair competition protection. ${ }^{31}$

The fact of registration was then a means of demarcating the subject matter of trademark and unfair competition law. Although the cases are less clear than this tidy division, technical trademark cases involved a property right protected by trademark law, whereas in unfair competition cases the complainant had no property interest in what was imitated. ${ }^{32}$ As a result, unfair competition protection was limited and contained effective constraints such as direct competition, intent to deceive, and diverted sales. Because the claim was based on no certain ground, such as property, courts were reluctant to cede these preconditions.

27 The 1881 Trademark Act-the nation's first federal trademark act-addressed only registration and the rights that flow from it. The 1870 Trademark Act was found unconstitutional by the Supreme Court. In re Trade-Mark Cases, 100 U.S. 82 (1879).

28 Only trade names that had been exclusively used for a period of ten years before the enactment of the statute were registrable under the 1905 Act. Trademark Act of 1905, ch. 592, § 5, 33 Stat. 724, 727.

29 See, e.g., H. Becker \& Co. v. C.A. Gambrill Mfg. Co., 38 App. D.C. 535, 537 (1912) (holding that "Orange Grove" is geographical and "not subject to registration as a technical trademark”); In re Wright, 33 App. D.C. 510, 512 (1909); see also Milton Handler, Unfair Competition, 21 Iowa L. Rev. 175, 182 (1936) ("The legal remedy for the protection of trademarks is known as trademark infringement. 'Unfair competition' is the remedy for trade names.").

30 "Trade names" were essentially the equivalent of today's marks that require secondary meaning for protection. See 15 U.S.C. $\$ 1127$ (2018); William Henry Browne, Treatise on the Law of Trade-Marks and Analogous Subjects $§ 91$ (2d ed. 1885) [hereinafter TradeMarks and Analogous Subjects (2d. ed. 1885)].

31 McCarthy, supra note 2, at § 1:15 (“Unfair Competition' was the name of th[e] part of the law which gave protection to 'trade names-designations that did not qualify as 'technical trademarks' but had acquired a secondary meaning as a mark.").

32 See Nims, supra note 1, at 24; Edward S. Rogers, Unfair Competition, 35 TMR 126, 126 27 (1945) ("The notion that there is 'property' in trade-marks as a separate thing was once quite generally entertained and for a while it served well enough, but it was very soon perceived that a trader's customers might be diverted by the imitations of things which were not trade-marks and in which property rights could not be maintained."). 


\section{A. The Former Constraints on Trademark Law}

Early trademark law engendered fears of monopolies much more than it does today. ${ }^{33}$ The monopoly rights created in patents and copyright were tolerable because they were necessary to achieve a greater public good. Trademarks, which were neglected by the Constitution, were seen to be unworthy of the cost. ${ }^{34}$

There were several features of early trademark law that served to constrain the rights of trademark owners so that they would not resemble monopoly rights. The subject matter of trademarks was narrowly construed; only a limited range within the broad range of indicia of source could qualify as a trademark. Most of what is today referred to as "trade dress" was excluded. An 1898 treatise author recorded examples of indicia of source ruled not subject to appropriation as a trademark:

There is no valid trade-mark in a piece of tin as a tag for tobacco, regardless of its color, shape, or inscription.... There is no right to the use of material substances on which a word, figures, or emblems, may be impressed or engraved.... Nor can there be a trade-mark in a peculiar method of arranging soap.... Nor for chewing-gum for form of sticks, or the shape or decoration of boxes. ${ }^{35}$

That litany of aspects of certain goods' presentation was taken from cases in which each had been purposefully copied to appropriate another's goodwill and deceive consumers. In none of those cases, however, did the law permit a remedy.

Other doctrines served to further limit the scope of a trademark owner's rights. The most significant among them was the limitation of actions to those in which the defendant's goods were the same as

33 Commentators, judges, and lawyers made frequent references to monopolies while discussing trademark policy. See generally Beverly W. Pattishall, Trademarks and the Monopoly Phobia, 50 Mich. L. Rev. 967 (1952).

34 Loughran v. Quaker City Chocolate \& Confectionery Co., 286 F. 694, 697 (E.D. Pa. 1923) ("Patents, copyrights, and trade-marks excite two deeply seated feelings. One is the feeling of any one who has originated anything of his right to claim an exclusive property in it and to the trade growing out of it. The other is a hatred of monopoly. The latter feeling gives way to the former so far as to grant limited monopolies through patents and copyrights. ... Mere dealers in commodities are prone to think themselves entitled to a like monopoly unlimited in time. This is a mistake."); Chadwick v. Covell, 23 N.E. 1068, 1069 (Mass. 1889) (Holmes, J.) ("The exclusive right to particular combinations of words or figures for purposes not less useful than advertising-for poetry, or the communication of truths discovered for the first time by the writer-for art or mechanical design has needed statutes to call it into being, and is narrowly limited in time.").

35 William Henry Browne, A Treatise on the Law of Trade-Marks and Analogous Subjects, Supp. at 15 (2d ed. 1898) [hereinafter Trade-Marks and Analogous Subjects (2d ed. 1898)] (emphasis omitted). 
the plaintiff's. ${ }^{36}$ Under the statute, a cause of action for trademark infringement existed only where a colorable imitation of a registered mark was used in connection with the sale of "merchandise of substantially the same descriptive properties" as those set forth in the registration. ${ }^{37}$ Not until the 1946 Lanham Act was this stringent standard discarded in favor of the looser likelihood of consumer confusion standard. ${ }^{38}$ Under the prior standard, one did not have the right to exclude others from adopting the same mark for even slightly dissimilar goods. ${ }^{39}$

Other common law doctrinal constraints limited trademark actions considerably. For instance, trademark owners were powerless to enjoin the use of their mark on the same goods when the defendants' commerce was intrastate rather than interstate. ${ }^{40}$ Another significant limitation was the requirement that the use of the mark by the defendant must be calculated to mislead the public with respect to the source of origin of the defendant's goods. ${ }^{41}$ Finally, trademark owners had no rights in any territory where they were not using the mark. In the landmark case of Hanover Star Milling Co. v. Metcalf, ${ }^{42}$ in which the defendant used the same mark on the same goods just 250 miles south of where the plaintiff conducted his business, the Supreme Court ruled that rights attach only to the goodwill possessed by the trader and plaintiff's goodwill did not extend to the defendant's area. ${ }^{43}$

36 See McCarthy, supra note 2, at $\S 1: 15$ (stating that early trademark law protection was granted "solely to shield the mark owner from having its customers confused and diverted away by a confusingly similar mark used by a direct rival.”). A trademark could only be infringed by a direct competitor. Id.

37 See Trademark Act of 1920, ch. 104, 41 Stat. 533; Trademark Act of Feb. 20, 1905, ch. 592, 33 Stat. 724; Trademark Act of 1881, ch. 138, 21 Stat. 502; Philco Corp. v. F. \& B. Mfg. Co., 170 F.2d 958, 959 (7th Cir. 1948).

38 The Lanham Act dispensed with the requirement that the parties' goods be of similar character. McCarthy, supra note 2, at $\S \S 3: 10-3: 12$.

39 See, e.g., Am. Steel Foundries v. Robertson, 269 U.S. 372, 380 (1926); Certain-Teed Prods. Corp. v. Phila. \& Suburban Mortg. Guar. Co., 49 F.2d 114, 115 (3d Cir. 1931); Nieman v. Plough Chem. Co., 22 F.2d 73, 79 (6th Cir. 1927), cert. denied, 277 U.S. 603 (1928); Beech-Nut Packing Co. v. P. Lorillard Co., 7 F.2d 967, 971 (3d Cir. 1925), aff'd, 273 U.S. 629 (1927); Peninsular Chem. Co. v. Levinson, 247 F. 658, 663 (6th Cir. 1917).

40 See, e.g., U.S. Printing \& Lithograph Co. v. Griggs, Cooper \& Co., 279 U.S. 156, 158 (1929); Pure Oil Co. v. Puritan Oil Co., 127 F.2d 6, 8 (2d Cir. 1942). Interstate commerce, necessary for federal regulation, could be satisfied only by the crossing of state line with the physical transport of goods from state to state. Otherwise, commerce was judged to occur only within the state.

41 As the Supreme Court made clear in Delaware \& Hudson Canal Co. v. Clark, "in all cases where rights to the exclusive use of a trade-mark are invaded, it is invariably held that the essence of the wrong consists in the sale of the goods of one manufacturer or vendor as those of another; and that it is only when this false representation is directly or indirectly made that the party who appeals to a court of equity can have relief." 80 U.S. (13 Wall.) 311, 322 (1871).

$42 \quad 240$ U.S. 403 (1916).

$43 \quad$ Id. at 420 . 
The sweet spot for trademark infringement involved a defendant using a colorable imitation of the plaintiff's registered mark in connection with the sale of identical goods. Pre-Lanham Act, falling outside of this zone could doom a plaintiff's case because there was no stable legal right apart from the severely curtailed rights found in trademark law. For example, in an 1885 case in which the defendant used deception to "obtain unfair advantage," the judge nonetheless denied relief, albeit with "with extreme reluctance," because of the absence of a legal right to enjoin unfair competition at that time. ${ }^{44}$ Some courts, however, gave in to the frustration engendered by the gaps in protection. In a case at around the same time in which the defendant deceived consumers by simulating the appearance of the plaintiff's goods, but had not copied the plaintiff's trademark, ${ }^{45}$ the court ruled for the plaintiff. It believed such deviousness could not be countenanced by the law. It was unfair competition, though no legal doctrine by this name then existed.

\section{B. The Growth of Unfair Competition Law}

Both trademark law and unfair competition law developed rapidly at the turn of the century. Frank Schechter reports that "in 1870 only one hundred and twenty-one trade-marks were registered ... while in 1923 almost fifteen thousand were registered." ${ }^{46}$ As Robert Bone has explained, this turn of the century growth resulted from three contributing events: the creation of nationwide markets spawning the need for consumers to familiarize themselves with brands rather than manufacturers; the diversification of product lines enabling manufacturers to extend their existing goodwill to new products; and the emergence of psychological advertising causing firms to invest their marks with emotional messages. ${ }^{47}$

44 Lehigh Valley Coal Co. v. Hamblen, 23 F. 225, 225-26 (N.D. Ill. 1885) ("The object of the defendants in causing an Illinois corporation to be created, bearing the same name as the complainant company, is obvious. They hope, by this means, to secure the benefit of part, at least, of the patronage which the complainant has acquired. Unwilling to engage in open, manly competition with the complainant and others carrying on the same business, the defendants resort to a trick or scheme whereby they hope to deceive the public and obtain an unfair advantage of the complainant. Such conduct might be fairly characterized more harshly; and it is with extreme reluctance that I deny the complainant the relief prayed for.”).

45 Avery \& Sons v. Meikle \& Co, 81 Ky. 73, 86-87 (1883) ("When a workman or manufacturer ... adopts and uses [a mark to indicate origin], and his reputation is thereby built up, it is to him the most valuable of property rights. Sound policy, which dictates the protection of the public from imposition, the security of the fruits of labor to the laborer, the encouragement of skillful industry, and, above everything, the inculcation of truth and honor in the conduct of trade and commerce . . . demands that such a reputation so gained should be free from the grasp of piracy.”).

$46 \quad$ Schechter, supra note 23, at 134.

47 See Robert G. Bone, Hunting Goodwill: A History of the Concept of Goodwill in Trademark Law, 86 B.U. L. Rev. 547, 576-82 (2006). 
Even though the first reported federal trademark case was not decided until 1844, ${ }^{48}$ and there was no effective trademark act until 1881, ${ }^{49}$ by 1885 William Henry Browne, the first U.S. treatise author on the subject-who was already publishing a second edition, observed that "no other branch of legal science has had a more rapid growth during the [past] twelve years" than trademark law. ${ }^{50}$

Unfair competition law, in contrast, was only then making its first appearance. In 1898-after a half century of reported U.S. trademark cases-Browne published a revised second edition of his treatise in which he announced that unfair competition had "generally been adopted by the courts." 51 Still, only one chapter of the treatise is devoted to the topic. It was titled "Rights Analogous to Those of Trade-Marks." 52 Presumably, the chapter was not titled "Unfair Competition Law" because that phrase would have been unintelligible in 1898. In that chapter Browne included "multifarious cases that are not strictly trade-mark matters, and are beyond recognized technical rules, but which are deemed worthy of protection." ${ }^{53}$ Permitting a cause of action in cases absent an actual trademark, unfair competition thus developed as a shadow around trademark law. ${ }^{54}$

A 1906 treatise on tort law suggests that while trademark rights were "conceived as an invasion of property," an action in unfair competition could not "be placed on the plane of invasion of property right," but is instead a "tort [that] is strictly one of fraud." 55 Yet the expansion of trademark rights over time has been enabled, in part,

48 Taylor v. Carpenter, 23 F. Cas. 742 (C.C.D. Mass. 1844) (No. 13,784). The first trademark case decided by a state court was decided in 1837. Thompson v. Winchester, 19 Pick. 214 (Sup. Ct. Mass. 1837). See also Schechter, supra note 23, at 134 ("Up to 1870 only sixtytwo trade-mark cases in all were decided by American courts.").

49 The first act of 1870 was found unconstitutional by the Supreme Court in 1879. The Trade-Mark Cases, 100 U.S. 82 (1879) (finding the Trademark Act of 1870 unconstitutional because Congress had no constitutional authority to regulate trademarks under Article 1, Section 8, Clause 8).

50 See Trade-Marks and Analogous Subjects (2d ed. 1885), supra note 30. Browne's first treatise was published in 1878. See William Henry Browne, Treatise on the Law of Trade-Marks and Analogous Subjects (1873). He published a new version of the second edition "revised and enlarged with supplement" in 1898. See Trade-Marks and Analogous Subjects (2d. ed. 1898), supra note 35. The first English trademark treatise was not published until 1873, just five years preceding the first American edition.

$51 \quad$ See Trade-Marks and Analogous Subjects (2d ed. 1898), supra note 35, at $§ 719$.

$52 \quad$ See id. Rogers notes that "Law writers did not know where to classify these cases. Digest compilers put them under an added paragraph heading 'Cases analogous to trade-mark cases." Rogers, supra note 35, at 127.

$53 \quad$ See Trade-Marks and Analogous Subjects (2d ed. 1898), supra note 35, at $§ 719$.

$54 \quad$ Rogers, supra note 32, at 126-27 ("it was very soon perceived that a trader's customers might be diverted by the imitations of things which were not trade-marks and in which property rights could not be maintained.").

551 Thomas Atkins Street, The Foundations of Legal Liability: Theory and Principles of Tort 421 (1906). 
by the absence of clarity about its basis; it was never anchored to one set principle. ${ }^{56}$ In his 1925 book on trademark law's historical foundations, Schechter reports that some courts resisted the proposition that trademark rights are based in property. ${ }^{57}$ This resistance to property foundation of trademarks ${ }^{58}$ added to the appeal of unfair competition claims based in tort. Whether or not a property right exists, the court had jurisdiction over the fraud. ${ }^{59}$

Where legal doctrine was absent, the tort of unfair competition allowed courts to be guided by morality. ${ }^{60}$ As one court simply

56 From the start, the rationale of trademark law has been a mix of consumer protection, commercial morality, and property rights. In one of the earliest reported trademark cases, the court weaves the three together as justification for interfering in a competitive relationship:

When we consider the nature of the wrong that is committed when the right of an owner of a trade-mark is invaded, the necessity for the interposition of a court of equity becomes still more apparent. He who affixes to his own goods an imitation of an original trade-mark, by which those of another are distinguished and owned, seeks, by deceiving the public, to divert and appropriate to his own use, the profits to which the superior skill and enterprise of the other had given him a prior an exclusive title. He endeavors, by a false representation, to effect a dishonest purpose; he commits a fraud upon the public, and upon the true owner of the trade-mark.

Amoskeag Mfg. Co. v. Spear, 2 Sand. Ch. 599, 605-06 (N.Y. Ch. 1849). See also Mark McKenna, The Normative Foundations of Trademark Law, 82 Notre Dame L. Rev. 1839, 1841 (2007) (arguing that trademark law was not originally intended to protect the consumer, but instead sought to protect producers from "illegitimate diversions of their trade by competitors").

57 Schechter, supra note 23, at 150 ("[t] $\mathrm{t}$ he main difficulties of the courts and also of textwriters has been ... the nature of trade-mark rights and the proper bases for the protection of these rights. The principal obstruction to the development of the law in accordance with the necessities of business has been the uncertainty of those administering or commenting upon the laws to whether or not trade-marks are what they term 'property.").

58 See, e.g., Hearings on H.R. 9041 Before the Subcomm. of Trade-Marks of the H. Comm. on Patents, 75th Cong. 53 (1938) [hereinafter Hearings on H.R. 9041] (statement by Rogers) ("[f] 50 years there has been a discussion in the cases whether a trade-mark is property, or not, and whether its infringement is a violation of a property right, or merely an actionable wrong or tort.").

59 As one court that eschewed the trademark/property theory noted,

[w]e are of opinion that it is not necessary to decide whether the plaintiff's label with the accompanying words and devices constituted a trademark, and as such the exclusive property of the plaintiff, for the reason that it is a fraud on a person who has established a business for his goods, and carries it on under a given name or with a particular mark, for some other person to assume the same name or mark, or the same with a slight alteration, in such a way as to induce persons to deal with him in the belief that they are dealing with a person who has given a reputation to that name or mark.

Pierce v. Guittard, 8 P. 645, 646-47 (Cal. 1885).

60 The Court of Appeals for the Second Circuit in International News was explicit about its reliance on morality: "If the facts are as we have now found them, no party asserts that the acts restrained by the injunction as issued can be justified, either in law or morals"; and "[i]t is immoral, and that is usually unfair to some one." 245 F. 244, 247, 252 (2d Cir. 1917). 
stated: “Unfair Competition' consists in selling goods by means which shock judicial sensibilities; and the Second Circuit has long been very sensitive." 61 Unfair competition law offered courts a vehicle for their desire to offer a remedy not in relation to a violation of a right, but in response to "odious" conduct. Where courts saw a wrong, they found a remedy in unfair competition. ${ }^{62}$

The legal basis of unfair competition in tort law resulted in a doctrine that was adaptable to new forms of deception for which there was no legal precedent. It was argued that this adaptability was necessary for the law to effectively keep up with the innovative "schemers." 63

It was in this context that the theory of "goodwill" took hold. As the Supreme Court explained in Hanover Star Milling Co., the law treats trademarks "as merely a protection for the good will, and not the subject of property except in connection with an existing business." ${ }^{4}$ That is, the property interest is not the trademark, but the underlying goodwill that the trademark represents. ${ }^{65}$ This theory enabled a blurring of the line between trademark infringement and unfair competition protection, as both were based on the same principle: "[e]ach is a trespass upon business good will." 66 The implications of this theory were profound. ${ }^{67}$ If the property interest is the goodwill, the chains of trademark fall away because the goodwill of a trader can be embodied in "the numberless

$61 \quad$ Margarete Steiff, Inc. v. Bing, 215 Fed. 204, 206 (S.D.N.Y. 1914).

62 One court desirous to find a remedy concluded that

$[\mathrm{u}]$ pon this bald statement of facts it cannot be gainsaid that defendant has done the plaintiff wrong, and it is said that for every wrong there is a remedy. . . 'Tis strange if plaintiff may be deprived of the fruits of a long course of honest and fair dealing in business by such wicked contrivances, and upon appeal to the courts for relief should be told there was no relief.

Weinstock, Lubin \& Co. v. Marks, 42 P. 142, 145 (Cal. 1895).

63 As one court reasoned,

the fact that the question comes to us in an entirely new guise, and that the schemer had concocted a kind of deception heretofore unheard of in legal jurisprudence, is no reason why equity is either unable or unwilling to deal with him.... [Defendant] is stealing its goodwill, a most valuable property, only secured after years of honest dealing and large expenditures of money; and equity would be impotent, indeed, if it could contrive no remedy for such a wrong.

Id. at 145 (emphasis added).

64 Hanover Star Milling Co. v. Metcalf, 240 U.S. 403, 412-13 (1916).

65 Nims, supra note 1, at 35 (explaining that "[i]t is the good-will . . and not trademarks or names that the court seeks to protect in unfair competition cases").

66 Edward S. Rogers, Comments on the Modern Law of Unfair Trade, 3 Ill. L. Rev. 551, 55558 (1909) ("Recently . . judges have begun to appreciate . . . that this business good will is the property to be protected against invasion."). According to Professor Bone, "[t]he goodwill-as-property theory" took firm hold in early 20th century and was "used to unify, at the level of general principle, the distinct but closely related torts of trademark infringement and unfair competition." Bone, supra note 47, at 572.

$67 \quad$ See Bone, supra note 47 , at 574. 
ways in which a purchaser is enabled to recognize the particular article he wants." 68 Suddenly, all of these are protected by unfair competition law. Another court indicated the law's breadth: "Where the goods of a manufacturer have become popular not only because of their intrinsic worth, but also by reason of the ingenious, attractive and persistent manner in which they have been advertised, the good will thus created is entitled to protection."69

Unfair competition law was thus extended beyond the tight boundary of trade names..$^{70}$ Whereas the categories of protection were formerly constrained in a way unrecognizable to a trademark lawyer today, unfair competition began to embrace the protection of a trader's use of "any artifice or contrivance for the purpose of representing his goods." 71 Writing in 1936, Professor Milton Handler explained that "[t]he concept of unfair competition has not been confined to the infringement of tradenames. It has been extended to the imitation of labels, packages, color, dress, form and appearance of articles." 72 When one recalls that the law had previously not allowed for the protection of the shape or decoration of boxes, ${ }^{73}$ this uncomplicated extension of unfair competition protection to trade dress is remarkable.

The option of an expanded unfair competition claim provided traders with a strategic maneuver around the strict requirements of trademark law. Thus in Gruelle v. Molly-'Es Doll Outfitters, Inc., where the trademark for RAGGEDY ANN was abandoned for nonuse, the plaintiff was able to successfully advance an unfair competition claim against a competitor who produced and sold "deceptively similar" dolls marked as "Raggedy Ann" and "Raggedy Andy." "It is no wonder that in 1917 one treatise author exclaimed that unfair competition law's "possibilities of growth and effectiveness are almost unlimited." 75

68 Rogers, supra note 66, at 555-58 ("good will could be . . represented in many other ways than by technical trade marks; by names not trade marks, by labels, by the get-up or dress, by the form of the goods themselves or the style of the enclosing package.”).

69 Hilson Co. v. Foster, 80 F. 896, 897-98 (C.C.S.D.N.Y 1897).

70 With today's eyes, we might categorize some of these early cases as involving trade dress. See, e.g., Weinstock, Lubin \& Co. v. Marks, 42 P. 142, 145 (Cal. 1895) (finding that the defendant used not only a similar name, but also copied the plaintiff's distinctive architecture).

71 Weinstock, Lubin \& Co., 42 P. at 145 (emphasis added) ("We think the principle may be broadly stated, that when one tradesman resorts to the use of any artifice or contrivance for the purpose of representing his goods or his business as the goods or business of a rival tradesman, thereby deceiving the people by causing them to trade with him when they intended to and would have otherwise traded with his rival, a fraud is committeda fraud which a court of equity will not allow to thrive.").

72 Handler, supra note 29, at 182.

73 See Trade-Marks and Analogous Subjects (2d ed. 1898), supra note 35, at 37.

74 Gruelle v. Molly-'Es Doll Outfitters, Inc., 94 F.2d 172, 175 (3d Cir. 1937).

$75 \quad$ Nims, supra note 1 , at viii. 
Unfair competition law, however, was not without its own constraints. A claim of unfair competition required the plaintiff to show that the defendant committed intentional fraud. ${ }^{76}$ Limitations on unfair competition protections are difficult to discern, however, because courts were more likely to describe the tort with an illustration rather than by supplying a definition or legal standard. 77 Still, fraudulent intent and economic injury are regularly included in these illustrations. ${ }^{78}$ Unfair competition claims involving descriptive or generic terms were also not likely to be successful. ${ }^{79} \mathrm{~A}$ trader, for instance, could not enjoin the use of the same name on the same goods if it was also the defendant's surname. ${ }^{80}$ In addition, the requirement of a competitive relationship was necessary ${ }^{81}$ although not always explicitly stated, since most unfair competition cases did involve direct competitors. Still, unfair competition law's adaptability to new situations meant that requirements could be swapped out as needed and the "courts gradually jettisoned the competition" requirement. ${ }^{82}$ One of the most famous examples of this requirement's circumvention is the case of Vogue Co. v. Thompson-Hudson Co. ${ }^{83}$ in which the owner of the trademark VOGUE for magazines sued a milliner who was marketing VOGUE hats. The Sixth Circuit, in reversing the district court's dismissal of the unfair competition claim due to lack of competition, declared that "there is no fetish in the word

76 See Pierce v. Guittard, 8 P. 645, 646-47 (Cal. 1885); Street, supra note 55, at 421 ("a fraudulent intent or its equivalent is essential to liability"); Handler, supra note 29, at 184 ("A trademark will be protected even against innocent infringement; a tradename, only against fraudulent simulation.”).

77 Handler, supra note 29, at 175.

$78 \quad 80 \mathrm{~F}$. at 897-98 ("The action is based upon deception, unfairness and fraud and when these are established the court should not hesitate to act."); Goldwyn Pictures Corp. v. Goldwyn, 296 F. 391, 401 (2d Cir. 1924) ("Fraud is the basis of [the] complaint in such cases.").

79 See, e.g., American Washboard Co. v. Saginaw Mfg., Co., 103 F. 281, 285 (6th Cir. 1900) (refusing to enjoin a washboard manufacturer who sold washboards that copied the plaintiff's habit of marking them "Aluminum" even though they were in fact made of zinc.). The court reasoned that because there was no private right of action based on fraud, a claim of deception of the public must be based on "the property rights of [the] complainant." Id.

80 See Thaddeus Davids Co. v. Davids Mfg. Co., 233 U.S. 461, 472 (1914) (refusing to enjoin defendant from using his surname even though plaintiff had registered it).

81 Frank I. Schechter, The Rational Basis of Trademark Protection, 40 Harv. L. Rev. 813, 824 (1927) ("if there [was] no competition, there [could] be no unfair competition."); Bone, supra note 47 , at 565-66.

82 Robert G. Bone, Schechter's Ideas in Historical Context and Dilution's Rocky Road, 24 Santa Clara Comput. \& High Tech. L.J. 469, 480 n.64 (2008). At the time, some commentators referred to competition-less unfair competition as "unfair dealing." See, e.g., 1 Rudolf Callmann, The Law of Unfair Competition and Trade-Marks § 8 (1945); Handler, supra note 29, at 179.

$83 \quad 300$ F. 509 (6th Cir. 1924). 
"competition." 84 Instead, it found that "[t]he invocation of equity rests more vitally upon the unfairness." 85 The court concluded that "The injury to A. is present, and the fraud upon the consumer is present; nothing else is needed." 86

The Supreme Court's decision in International News in 1918 represents the high water mark of common law unfair competition expansion. ${ }^{87}$ In deciding that International News Service engaged in actionable conduct by taking Associated Press's news stories from publicly available sources, rewriting them, and selling them as its own, the majority found itself in need of a source of law. Unfair competition became the vehicle to sanction undesirable behavior that did not run afoul of any property or contract right. The Court found it "unfair" due to the "unauthorized interference" with the "normal operation of complainant's legitimate business precisely at the point where the profit is to be reaped, in order to divert . . . the profit from those who have earned it to those who have not; with special advantage to defendant ... because of the fact that it is not burdened with any part of the expense." 88 Such an act "speaks for itself, and a court of equity ought not to hesitate long in characterizing it as unfair competition." 89

The law had come a long way from protecting technical trademarks to protecting goodwill, and from protecting against trespasses to property to protecting against reaping where one has not sown. This shift occurred in the common law in a matter of decades, but it was not yet reflected in statutory law.

\section{THE SINGULAR CONTRIBUTIONS OF EDWARD ROGERS}

Edward S. Rogers was one of the foremost experts on U.S. trademark and unfair competition law in the first half of the twentieth century. ${ }^{90} \mathrm{He}$ was one of a handful of trademark law

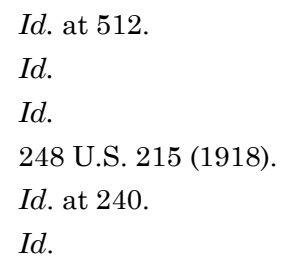

90 Miles J. Alexander, Reflection, Former Editors-in-Chief, 101 TMR 7, 9 (2011) ("[Rogers was] perhaps the greatest trademark scholar and lawyer in the first half of the 20th century."); Chafee, supra note 21, at 1289 ("[Rogers was] one of the leading American writers and practitioners in the field."); Bone, supra note 47, at n.119 ("[Rogers was] the most famous and prolific trademark writer in the early twentieth century."). At the time of his death, Rogers was so well regarded in U.S. trademark law that the Trademark Reporter devoted an entire volume to his legacy. In Memoriam, Edward S. Rogers Memorial Edition, 62 TMR 175-265 (1972). 
specialists in the United States prior to World War I. ${ }^{91} \mathrm{He}$ cofounded the first firm to specialize in trademark law in the U.S. ${ }^{92}$ and argued or briefed almost half of all of the trademark cases that the Supreme Court heard prior to the passage of the Lanham Act. ${ }^{93}$ By the 1920s, Rogers had become known as the "Dean of the Trademark Bar." 94

Rogers is also hailed as the "father of the Lanham Act." ${ }^{55}$ As a result of his knowledge and esteem, in 1920, Rogers was appointed by the Patent, Trademark, and Copyright Section of the American Bar Association as chairman of a committee to draft a new trademark bill to supplant the Trade Mark Act of 1905. ${ }^{96}$ The bill he drafted ultimately became the 1946 Lanham Act, ${ }^{97}$ although it was originally known as the "Rogers Bill." 98

Rogers was a successful practitioner as well as a prolific scholar. His 1914 book, Good Will, Trade-Marks and Unfair Trading,99 remained one of the leading texts in trademark law for decades. ${ }^{100}$ As the title suggests, the book both advances the theory of goodwill and the extension of protection against unfair competition, although that terminology had yet to be adopted. ${ }^{101}$ Rogers's writing indicates that he was fairly obsessed with the topic of unfair competition law. On this subject alone he wrote one book $^{102}$ and published eleven other papers. ${ }^{103}$ Stephen Ladas, another esteemed trademark

91 Keith M. Stolte, A Response to Jerome Gilson's Call for an Overhaul of the Lanham Act, 94 TMR 1335, 1346-1348 (2004).

92 William T. Woodson, A Profile of Edward S. Rogers, 62 TMR 177, 177 (1972) (stating that in 1900 the firm Reed and Rogers specialized in trademark law). Rogers represented corporate clients such as Thomas Edison, Coca-Cola, Standard Oil, General Mills, Singer Sewing Machines, Quaker Oats, Corning Glass, and Life Savers. Obituary, E.S. Rogers, Expert on Patent Law: Board of Chairman of Sterling Drug Co. Dies-Sponsored Many Fair-Trade Statutes, 74, N.Y. Times, May 23, 1949.

93 Rogers argued or briefed 12 of the 40 pre-Lanham Act trademark cases heard by the Supreme Court before the Lanham Act was enacted.

94 Pattishall, supra note 33, at 967; Julius R. Lunsford Jr, Foreword, 62 TMR iv (1972).

95 Miles J. Alexander, 100th Anniversary Issue: Reflections of Former Editors-in-Chief, 101 TMR 9, 9-10 (2011); see also Sara Stadler Nelson, The Wages of Ubiquity in Trademark Law, 88 Iowa L. Rev. 731, 755 (2003) (calling Rogers the "father of the Lanham Act").

96 Woodson, supra note 92 , at 186-87.

97 See Edward S. Rogers, The Lanham Act and the Social Function of Trademarks, 14 Law \& Contemp. Probs. 173, 180 (1949) (recounting how he drafted what was introduced by Congressman Lanham in 1938 as the original bill based on ABA committee meetings).

98 Woodson, supra note 92, at 187.

$99 \quad$ Edward S. Rogers, Good-Will Trade-Marks and Unfair Trading (1914).

100 See Woodson, supra note 92, at 186 (stating that Rogers' book "was and still is often quoted as authority").

101 See, e.g., Rogers, supra note 66, at 555.

102 Rogers, supra note 97.

103 Edward S. Rogers, Business Good-Will and Trade-Marks Nationally and Internationally Considered, 34 TMR 281 (1939); Rogers, Comments on the Modern Law of Unfair Trade, 3 Ill. L. Rev. 551 (1909); Edward S. Rogers, Doctrine of Unfair Trade, 7 Mich. L. Rev. 409 
expert, credits Rogers with contributing the concept of "unfair trade" to trademark law, which was understood as encompassing "any act, not necessarily fraudulent, which actually interferes with the normal course of trade to the disadvantage of another." 104 According to Professor Walter Derenberg, Rogers "was one of the first to recognize the need for a federal law of unfair competition ... [with a] 'catchall' provision against 'all forms of unfair competition,' a proposal which had been advocated by Mr. Rogers as far back as 1909." 105

Rogers's promotion of unfair competition law went beyond scholarship. In his practice, Rogers successfully advanced claims of unfair competition that extended the law's reach. ${ }^{106}$ In his cases and in his writing, Rogers advocated for flexibility in the law because not all devious acts could be foreseen. He warned that "by the time the judicial machinery arrives at a place where the pirate was yesterday, ... that elusive person has moved [to] a place where the courts will not reach until tomorrow-and is there engaged in doing something which will enable him to advantage himself at someone's else expense in some manner hitherto unthought of." 107

Rogers also understood that traders may encounter such "pirates" in foreign lands as well. Likely because many of his clients were contemplating a global marketplace, he was concerned about practices such as the pre-emptive adoption and registration of U.S.

(1909); Edward S. Rogers, New Concepts of Unfair Competition under the Lanham Act, 38 TMR 259 (1948); Edward S. Rogers, New Directions in the Law of Unfair Competition, 74 N.Y. L. Rev. 317 (1940); Edward S. Rogers, Predatory Price Cutting as Unfair Trade, 27 Harv. L. Rev. 139 (1913); Edward S. Rogers, Unfair Competition, 35 TMR 126 (1945); Edward S. Rogers, Unfair Competition, 17 Mich. L. Rev. 490 (1919); Edward S. Rogers, Foreword to Walter J. Derenberg, Trade-Mark Protection and Unfair Trading lxix (1936); Edward S. Rogers, The Legal Side of Fair Trade, Speech at the Annual Meeting of Association of National Advertisers Inc. (1937).

104 Stephen P. Ladas, Patents, Trademarks, and Related Rights: National and International Protection 1702 (1975).

105 Walter J. Derenberg, The Contribution of Edward S. Rogers to the Trademark Act of 1946 in Historical Perspective, 62 TMR 189, 194 (1972) (citing Rogers, supra note 66).

106 See, e.g., Larson v. Wrigley, 20 F.2d 830 (7th Cir. 1927) (advancing an unfair competition claim based on Wrigley's SPEARMINT gum trade dress); Aunt Jemima Mills Co. v. Kirkland Distributing Co., 48 App. D.C. 248 (D.C. Cir. 1918) (arguing that his client's use of the image of Aunt Jemima on pancake flour should prevent the registration of a mark for flour consisting of "the bust of a negro holding a piece of watermelon under the chin, surmounted by the words 'Good Enuf"); American Trading Co. v. H.E. Heacock Co., 285 U.S. 247 (1932) (arguing that a common surname should be protected against unfair competition when it acquires secondary significance as indicating a particular trader); Timken Roller Bearing Co. v. Leterstone Sales Co., 27 F. Supp. 736 (N.D. Ill. 1939) (arguing that a misleading use of an arguably generic word was unfair competition); Premier-Pabst Corp. v. Elm City Brewing Co., 9 F. Supp. 754 (D. Conn. 1935) (arguing that a competitor's use of "Olde Maestro" for beer was unfair competition when his client's beer was the sponsor for the radio show of a performer known as the Olde Maestro).

107 Rogers, New Concepts of Unfair Competition under the Lanham Act, supra note 103, at 270 . 
marks abroad, or the marking of foreign goods so as to suggest an origin in the United States. ${ }^{108}$

\section{THE 1929 INTER-AMERICAN TRADEMARK CONVENTION}

Given Rogers's expertise and reputation in the field of trademark law, it was not surprising that he would have been appointed as one of the three U.S. delegates to the 1929 PanAmerican Trademark Convention, a convention tasked with drafting a new trademark treaty for the Americas. By 1929, Rogers had been drafting the new trademark act for nine years. Four year earlier, the Paris Convention for the Protection of Industrial Property had undergone a revision, which added provisions on unfair competition. ${ }^{109}$ Rogers would have seen the potential to extend those protections across the Americas in this new multilateral agreement. No doubt this project would have appeared to Rogers as momentous work.

The 1929 convention was an outgrowth of several preceding PanAmerican conferences-a forty-year-long effort to create a PanAmerican Union for trade in the Americas. These conferences grew out of the Pan-Americanism movement in the United States in the early twentieth century whose objectives included replacing Europe as the dominant power in the region, using institutionalism as an alternative to U.S. territorial expansionism and military interventions, and cultivating Latin America as a commercial marketplace for goods manufactured in the United States. ${ }^{110}$ The ambitions of the union even included the creation of a common customs union, railway system, and currency, among other things. ${ }^{111}$

108 A New Way of Dealing with Foreign Trade-Mark Piracy, 8 Bull. of the U.S. Trade-Mark Assoc. 338 (1912) (recounting how Rogers sued a defendant in a New York state court who had preemptively registered BIG BEN in Mexico); Edward S. Rogers, One Way to Stop the Foreign Good-Will Pirate, 81 Printer's Ink 36 (1912); Edward S. Rogers, Your Trade-Mark in Foreign Markets: How to Prevent Piracy and Other Pitfalls in Registering Your Trade-Mark in Foreign Lands, 26 System: The Magazine of Business 363 (1914).

109 See International Convention for the Protection of Industrial Property, art. 10bis, Nov. 6, 1925, 47 Stat. 1789 (modified at The Hague); International Convention for the Protection of Industrial Property, art. 10bis, June 2, 1934, 53 Stat. 1748.

110 The Cuban nationalist José Martí, who attended the 1889 Congress as a journalist, reported that the United States invited the other American nations to join a union only because it was "glutted with unsaleable merchandise and determined to extend its dominions in America." José Martí, On the Pan-American Congress, La Nación, December 19-20, 1889, available at https://faculty.chass.ncsu.edu/slatta/hi453/PS/ marti.htm (last visited June 28, 2020).

111 Fifth International Conference of American States, Special Handbook for the Use of the Delegates 6 (1922) (listing the topics the Conference was called upon to consider: " 1 . To preserve the peace and promote the prosperity of the American states. 2. Formation of an American customs union. 3. Establishment of regular and frequent communication between the American States. 4. Establishment of a uniform system of customs 
The 1929 convention was the culmination of efforts dating back to 1889 to harmonize trademark protection in the Americas. There had been six Pan-American conventions dealing with trademarks that preceded it, but those conventions proved to be substantively deficient. ${ }^{112}$ The first Pan-American convention was as early as 1889, just years after 1883 Paris Convention, the first multilateral industrial property treaty. One reason for the interest in concluding regional agreements on intellectual property in the Americas was that most Latin American states were not then members of the Paris Union. ${ }^{113}$ The 1929 convention included nineteen signatory countries, ${ }^{114}$ but only ten states ultimately ratified the convention: Colombia, Cuba, Guatemala, Haiti, Honduras, Nicaragua, Panama, Paraguay, Peru, and the United States. The convention entered into force on April 2, 1930, and remains in force today in every one of the original member states. ${ }^{115}$

regulations. 5. Adoption of a uniform system of weights and measures, and laws to protect patents, copyrights, and trade-marks. 6. Adoption of a common silver coin. 7 . Agreement upon the recommendation for adoption to their Governments of a definite plan of arbitration. 8. Consideration of other matters relating to the welfare of the several countries, which may be presented at the Conference.").

112 The six conventions were ratified in 1889, 1902, 1906, 1910, 1923, and 1929.

113 Only Brazil, Cuba, and Mexico became members of the Paris Union by 1929. Brazil was a founding member of the Paris Convention in 1883, and Mexico and Cuba ratified in 1903 and 1904, respectively. The United States ratified the Paris Convention in 1887. A few other Latin American states were original signatories to the Paris Convention, only to denounce it shortly thereafter. The Dominican Republic acceded in 1884, but denounced in 1888. Guatemala acceded in 1884, but denounced in 1894. Ecuador acceded in 1884, but denounced in 1885. Ladas, supra note 104, at 1745 n.1; see WIPOAdministered Treaties Paris Convention, World Intellectual Property Organization ("WIPO") (last visited Feb. 15, 2020), https://www.wipo.int/treaties/en/ShowResults. jsp?lang=en\&treaty_id=2. During the 1929 Pan American Conference, it was stated that Brazil and Cuba intended to withdraw from the Paris Convention. Pan American Trademark Conference, Minutes of the Plenary Sessions and of the Committees of the Conferences, Feb. 11-20, 1929, p. 5 [hereinafter Minutes of the Plenary Sessions]. Cuba was also a member of the Madrid Agreement of 1891. See WIPO-Treaties and Contracting Parties Madrid Agreement, WIPO (last visited Feb. 18, 2020) https://www.wipo.int/treaties/en/remarks.jsp?cnty_id=1292C. In 1906, Argentina invited the United States Trademark Association ("USTA") to comment on its domestic trademark law. International Trademark Association ("INTA"), About INTA History, available at https://web.archive.org/web/20180513071236/www.inta.org/ history/pages/history.aspx (last visited June 28, 2020). Similarly, in 1908, Ecuador asked the USTA to propose a trademark law, which was to become the model for other Latin American countries. Id.

114 The signatories to the convention were Bolivia, Brazil, Chile, Colombia, Costa Rica, Cuba, the Dominican Republic, Ecuador, Guatemala, Haiti, Honduras, Mexico, Nicaragua, Panama, Paraguay, Peru, the United States, Uruguay, and Venezuela. InterAmerican Convention, supra note 8.

115 See WIPO, Contracting Parties/Signatories: General Inter-American Convention for Trade-Mark and Commercial Protection, available at http://www.wipo.int/wipolex/en/ other_treaties/parties.jsp?treaty_id=353\&group_id=21 (last visited Oct. 22, 2019). 


\section{A. The Convention's Innovative Text}

Several features of the 1929 convention distinguish it from the preceding Pan-American conventions. The 1929 convention was the first to include specific protections against unfair competition. This fact may not be surprising given the 1925 addition of unfair competition protections in the Paris Convention. The 1929 convention, however, did more than simply copy the Paris Convention's provisions. It devoted an entire chapter to unfair competition. The importance of unfair competition protection can also be seen in the preamble of the convention, which states that the contracting states were "animated by the desire to reconcile the different juridical systems which prevail in the several American Republics" and resolved to negotiate the convention "for the protection of trade marks, trade names, and for the repression of unfair competition and false indications of geographical origin."116 The text of the agreement certainly supports this statement and appears to have Rogers's imprint on it.

Rogers was no ordinary delegate to this convention; it would be impossible to overstate his contributions. There is reason to believe that he was chiefly responsible for the text. I have conducted extensive research to determine the origins of the draft text that ultimately became the final text of the agreement. The origins of this text are intriguing because of the innovative approach the convention takes. Many of the provisions in the convention went beyond both U.S. and international law.

The drafting of the text of the 1929 convention did not follow the prescribed procedure. Officially, the delegates were to meet to discuss a draft text prepared by an appointed committee. ${ }^{117}$ That committee consisted of three Latin American diplomats, none of whom were trademark experts. ${ }^{118}$ The draft text that the committee ultimately produced was preoccupied with creating a registrationbased system for the Americas as an alternative to the Madrid

116 Inter-American Convention, supra note 8.

117 A resolution was made at the previous conference held in Havana a year earlier to appoint a special committee of the governing board of the Pan American Union to draft a text for the delegates to consider at the Washington conference. A draft was thus prepared by a committee composed of the Cuban Ambassador to United States and ministers from Ecuador and Uruguay and submitted to the conference on November 23, 1928. Pan American Trademark Conference, Preparatory Data for the Pan American Trade Mark Conference: Report of the Committee of the Governing Board of the Pan American Union, Feb. 11, 1929. The governments were requested to send to the Pan American Union any "suggestions and observations that may be utilized in the formation of the bases of a project that shall be prepared by the Pan American Union and that shall serve as a basis of discussion when the conference convenes." Stephen P. Ladas, Pan American Conventions on Industrial Property, 22 Am. J. Int'l L. 803 (1928) (citing Documentary Information Compiled by the Pan American Union relative to the Pan American Trade Mark Conference, Washington, 1928, p. 1.). 
Arrangement. ${ }^{119}$ As a result, this draft did not contain a single provision on unfair competition protection.

Just prior to the conference, Dr. Stephen P. Ladas ${ }^{120}$ published a book titled The International Protection of Trade Marks by the American Republics. ${ }^{121}$ Ladas was explicit about his objective in publishing the book, stating that it was meant to "facilitate the work of the conference of trade mark experts and specialists of the American countries, meeting at Washington, February 11, 1929."122 In the book, Ladas sharply criticized the committee's official draft as inadequate and, rather presumptuously, considering he was not a delegate, offered his own draft text as a substitute. Apparently, the Ladas draft was devised by a group of U.S. trademark experts who met in New York after the committee's official draft was circulated. ${ }^{123}$ Other than Ladas, the members of the group remain anonymous, but it is likely that Rogers was among them.

The Ladas draft was radically different from the committee's. It marked the first time unfair competition was mentioned in any text associated with the Pan-American efforts, and its inclusion in the convention therefore resulted from the efforts of the U.S. experts, and not the Latin American delegates. Ladas not only included a provision modelled on the then four-year-old article 10bis of the Paris Convention, ${ }^{124}$ but he also proposed a model law of unfair competition in addition to the draft treaty. ${ }^{125}$

However, neither the official committee draft nor the unofficial Ladas draft ended up serving as the basis for the conference negotiations. Instead, when the delegates assembled in Washington on February 11, 1929, a delegate from Cuba proposed substituting the committee's draft with a completely different draft ostensibly prepared by the Cuban delegation "[f]or the purpose of expediting the work of the Conference." ${ }^{26}$ The committee's official draft was thus promptly discarded and substituted with the Cuban draft,

119 Stephen P. Ladas, The International Protection of Trade Marks by the American Republics 53 (1929).

120 Ladas, who emigrated from Greece in the mid-1920s, was a U.S. practitioner and scholar of international intellectual property law who went on to publish numerous books and articles and to serve as a U.S. delegate to the Paris Convention. Obituary, Dr. Stephen P. Ladas, Patent Lawyer, 77, N.Y. Times, Mar. 15, 1976, at 33.

121 Ladas, supra note 119. Ladas had previously published an article titled, Pan American Conventions on Industrial Property, 22 Am. J. Int'l L. 803 (1928).

122 Ladas, supra note 119 , at v.

123 In a footnote in a book published years later, Ladas referred to "preparatory work" done by U.S. trademark experts - including him - that formed the basis of his draft. Ladas, supra note 104, at 1754 n.40 (suggesting that the substituted draft predominantly reflected the results of "preparatory work" undertaken in the U.S. by trademark experts).

124 See International Convention for the Protection of Industrial Property, art. 10bis, Nov. 6, 1925, 47 Stat. 1789 (modified at The Hague).

125 See Ladas, supra note 119, at 80-82.

126 Minutes of the Plenary Sessions, supra note 113, at 4. 
which was clearly based on Ladas's draft, not the initial committee's draft, given its striking similarity to the former.

Without entertaining too much conspiratorial conjecture, it seems implausible that the substitute draft was the work of the two Cuban delegates, neither of whom were trademark experts. ${ }^{127}$ Ladas later acknowledged that this draft was prepared "with the cooperation of the United States delegation."128 This author suspects that Ladas may have substantially understated the role of the U.S. delegates. Perhaps by remaining an anonymous drafter, Rogers was better positioned to advocate for the draft without seeming to be pushing his own agenda. Thus, the draft appeared to be contributed by another state's delegate and was supported by a published book by an authority unconnected with the proceedings.

After agreeing to accept this new draft text as the basis of negotiations, the conference then agreed to appoint four committees to carry out the necessary work. Remarkably, especially as no previous convention had discussed the topic, one of the four committees was devoted to "Unfair Competition and False Indication of Origin." A second committee was designated as a "drafting committee" and was limited to only four delegates. ${ }^{129}$ Rogers found his way onto the drafting committee. ${ }^{130}$

Rogers now had a golden opportunity to codify the law of unfair competition on a grand scale. He had a well-developed conception of what the law should prohibit and how to best articulate these new standards. By this time, he already had years of experience drafting the U.S. trademark act. ${ }^{131}$ Significantly, he also knew that his

127 Moreover, the Cuban delegate who proposed the new draft was Dr. Orestes Ferrara, the Cuban Ambassador to the United States. As "a strong advocate of close economic ties between Cuba and the United States," Ferrara was criticized for his "pro-U.S. sympathies" as an "annexationist." See Julius Robert Benjamin, The United States and Cuba: Hegemony and Dependent Development 1880-1934, at 45-46 (1974); see also Dr. Orestes Ferrara, El Panamericanismo y la Opinion Europea (1930) (defending the Monroe Doctrine and describing U.S. intervention in Caribbean affairs as "paternalistic" rather than imperialist). Francis White, the chairman of the U.S. delegation, was then serving as Assistant Secretary of State for Latin American Affairs and had close connections in Cuba. See Rosalie Schwartz, Flying Down to Rio: Hollywood, Tourists, and Yankee Clippers 230 (2004).

128 Ladas, supra note 104, at 1755.

129 Press Release, Pan American Trade Mark Conference, Pan American Trade Mark Conference, Washington DC-Pan American Trade Mark Conference Opens Sessions 2 (Feb. 11, 1929) (each committee represented one of the four languages spoken by the delegates).

$130 \quad$ Minutes of the Plenary Sessions, supra note 113, at 3.

131 Rogers began drafting a new trademark act in 1921 in preparation for the ABA committee meeting, which later proposed and approved Rogers' draft, known as the "Vestal Bill." McCarthy, supra note 2, at § 5:4. In 1937, Representative Lanham, who was then Chairman of the House Patent Committee, invited Rogers to share his personal draft act based on the Vestal Bill. This draft became the basis of the Trademark Act of 1946. See The Vestal Bill, H.R. 7118, 72d Cong. (1st Sess. 1931); Sondra Levine, Part 
conception of unfair competition was not then a feature of U.S. law. Nevertheless, in a strategy that is still utilized by U.S. intellectual property treaty negotiators today, U.S. law was touted as a model for all jurisdictions in the Americas to follow. ${ }^{132}$ After the convention was finalized but before it was ratified, the U.S. delegation produced a public relations document titled The Advantages Accruing to American Citizens from the General Convention for Trademark and Commercial Protection. ${ }^{133}$ In it, the U.S. delegation highlights the treaty's protections against unfair competition. It states that the convention "extends through Latin America common law principles of honest trading which have been enforced in the United States for forty years under the elastic jurisdiction of our equity courts." 134 No doubt this argument that the protections in the act were already the law in the United States was also employed in negotiating the convention.

\section{B. Unfair Competition in the Inter-American Convention}

Chapter IV of the convention is titled "Repression of Unfair Competition" and sets out both broad and detailed protections against acts of unfair competition that went well beyond the then existing protection under U.S. common law, statutory law in any of the member states, and international convention. ${ }^{135}$ In addition to

One: The Common Law, the States, and Historical perspectives: The Origins of the Lanham Act, 19 J. Contemp. Legal Issues 22, 24-25 (2010).

132 See Ruth L. Okediji, Back to Bilateralism? Pendulum Swings in International Intellectual Property Protection, U. Ottawa L. \& Tech. 125, 143-47 (2004) (discussing the "bilateralism" strategy used by the United States wherein bilateral commercial treaties are "used as instruments of foreign relations by the United States" in extending international intellectual property protections.).

133 Press Release, U.S. Delegation to the Inter-American Convention, The Advantages Accruing to American Citizens from the General Convention for Trademark and Commercial Protection 2 (Feb. 11, 1929).

$134 \quad I d$.

135 Chapter IV of the Inter-American Convention states that "[e]very act or deed contrary to commercial good faith or to the normal and honorable development of industrial or business activities shall be considered as unfair competition and, therefore, unjust and prohibited" and lists acts that "are declared to be acts of unfair competition" including:

(a) Acts calculated directly or indirectly to represent that the goods or business of a manufacturer, industrialist, merchant or agriculturist are the goods or business of another manufacturer, industrialist, merchant or agriculturist of any of the other Contracting States, whether such representation be made by the appropriation or simulation of trade marks, symbols, distinctive names, the imitation of labels, wrappers, containers, commercial names, or other means of identification;

(b) The use of false descriptions of goods, by words, symbols or other means tending to deceive the public in the country where the acts occur, with respect to the nature, quality, or utility of the goods; 
the protections in this chapter, trade names-that species of unregistered marks addressed in U.S. unfair competition law-are protected in Chapter III, and "false indications of geographical origin or source" are protected in Chapter V. Unfair competition thus pervades the convention.

The chapter on unfair competition sets out specific acts that are "declared to be acts of unfair competition" and therefore "prohibited." 136 These include:

Acts calculated directly or indirectly to represent that the goods or business of a manufacturer, industrialist, merchant or agriculturist are the goods or business of another manufacturer, industrialist, merchant or agriculturist of any of the other Contracting States, whether such representation be made by the appropriation or simulation of trade marks, symbols, distinctive names, the imitation of labels, wrappers, containers, commercial names, or other means of identification. 137

This prohibition is obviously based on passing off, but is formulated more expansively than contemporary U.S. law. ${ }^{138}$ Actionable conduct includes misrepresentation of the origin of goods "indirectly," and requires merely a "simulation." There appears to be no requirement of direct competition, economic injury, or proof of a likelihood of consumer confusion. The protection applies not only to goods, but also to a trader's "business" and may therefore reach services. Finally, protection is not limited to devices that would constitute protectable unregistered marks. For instance, the only "means of identification" that is qualified by "distinctive," is "names." Presumably, others means of identification could be descriptive and yet still be protected.

In addition to the Inter-American Convention and Protocol, the 1929 Pan-American Trademark Convention adopted 12 resolutions, which were annexed to the Final Act. The Seventh Resolution was a "Declaration of Principles on Unfair Trade Practices," stating:

(c) The use of false indications of geographical origin or source of goods, by words, symbols, or other means which tend in that respect to deceive the public in the country in which these acts occur; [and]

(d) To sell, or offer for sale to the public an article, product or merchandise of such form or appearance that even though it does not bear directly or indirectly an indication of origin or source, gives or produces, either by pictures, ornaments, or language employed in the text, the impression of being a product, article or commodity originating, manufactured or produced in one of the other Contracting States.

Inter-American Convention, supra, note 8, at 2934.

Id.

Id. at 2932 .

It is possible that "calculated" implies an intent requirement. 
That every act including breach of contract without just cause or which discredits the products or methods of a competitor; commercial bribery; enticing employees of a competitor to obtain confidential information with respect to his activities; false use of testimonials, warrant and appointments and false statements of membership in associations; and in general every act which tends to secure the patronage of a competitor through intimidation or coercion, is declared unfair and fraudulent. ${ }^{139}$

According to this resolution, the delegates' view of unfair competition was expansive and extended beyond source confusion and false advertising. The convention details proscribed acts and yet state protections broadly rather than as technical rules, which could be evaded by crafty "parasites," as Rogers repeatedly called them. ${ }^{140}$ The text also formulated large areas of rights not previously addressed by U.S. law, such as geographical indications protection. ${ }^{141}$

The convention remains the strongest commitment to unfair competition protection in international law to date. The specificity and breadth of protections against unfair competition contained in the Inter-American Convention distinguish it from other international agreements. The Paris Convention did not provide any protection against unfair competition until the 1900 revision, ${ }^{142}$ and that text merely stated that such protection should exist. Not until 1925 did the convention attempt to delineate acts of unfair competition. The 1925 text proclaimed that "[a]ll acts contrary to honest usage in industrial or commercial matters" and "[a]cts of any

139 Final Act, General Inter-American Convention for Trade-mark and Commercial Protection, Feb. 20, 1929, 46 Stat. 2907, 124 L.N.T.S. 357.

140 See, e.g., Rogers, supra note 97 , at 76 ("[i]n the ordinary affairs of life the average business man takes reasonable precautions, but when it comes to adopting a trade-mark ... upon something which he may own and he may not-which may be his exclusive property and which he may have to share with every conscienceless parasite with more covetousness than decency"). Rogers uses the term "parasite" twelve times in his book. Id. at 82, 125, 135, 137, 158, 161, 203, 229, 264, 275, 281; see also Edward S. Rogers, Ingenuity of the Infringer and the Courts, 11 Mich. L. Rev. 358, 363 (1913); Rogers, supra note 32, at 128; Rogers, New Concepts of Unfair Competition under the Lanham Act, supra note 103, at 257.

141 See Christine Haight Farley, The Pan-American Trademark Convention of 1929: A Bold Vision of Extraterritorial Meets Current Realities, in Trademark Protection and Territoriality: Challenges in the Global Economy 58, 64-67 (Irene Calboli \& Edward Lee eds., 2014).

142 International Convention for the Protection of Industrial Property, art. 10bis, Dec. 14, 1900, 32 Stat. 1936, 1940 (revised at Brussels) ("Those entitled of right under the Convention (art. 2 and 3), shall enjoy, in all the States of the Union, the protection accorded to citizens or subjects against unfair competition."). That provision was revised in 1911 to read: "All the contracting countries agree to assure to the members of the Union an effective protection against unfair competition." International Convention for the Protection of Industrial Property, June 2, 1911, 38 Stat. 1645, 1663 (revised at Washington). 
kind whatsoever tending in any way to create confusion with the merchandise or products of a competitor" 143 constitute unfair competition. Thus, at that time under the Paris Convention, actionable conduct must be dishonest as per industry practice, ${ }^{144}$ between competitors, and cause consumer confusion. Intriguingly, none of these limitations were included in the Inter-American Convention drafted four years later. Although Article 10bis of the Paris Convention was subsequently revised in 1934 and 1958, these limitations persist. ${ }^{145}$

In addition to providing stronger and more detailed protections against unfair competition than the Paris Convention, the InterAmerican Convention also resolved one of the most vexing issues for intellectual property owners by providing them with an effective means of enforcing the rights granted in the treaty. Like the Paris Convention, the Inter-American Convention states: "Each of the Contracting States, in which it does not yet exist, hereby agrees to establish a protective service, for the suppression of unfair competition . . ." 146 This obligation resembles the approach of other international treaties to enact domestic laws where necessary to ensure the rights granted by the treaty will be given effect in each contracting state. Under this approach, intellectual property owners are at the mercy of member states to fulfill their obligations. In contrast with these other treaties, however, the Inter-American Convention anticipates member states' dereliction. Article 21

143 See International Convention for the Protection of Industrial Property, art. 10bis, Nov. 6, 1925, 47 Stat. 1789 (modified at The Hague); International Convention for the Protection of Industrial Property, art. 10bis, June 2, 1934, 53 Stat. 1748. The minutes of the Hague Conference that produced this revision indicate that "any means whatever" should include: "marks, registered or not, commercial names, names of business houses, titles of printed matter, get-up of goods, form of packages, shop signs-briefly, all signs used by a manufacturer or merchant to distinguish his trade and his merchandise from those of his competitors and also allegations relating to the origin of the products or merchandise." See Ladas, supra note 104, at 1706.

144 Compare the Paris Convention's insistence on dishonesty with the Inter-American Convention's language: "contrary to commercial good faith or to the normal and honorable development of industrial or business activities." Inter-American Convention, supra note 8, at 2930 (art. 20). Even though the French phrase "concurrence déloyale" was translated into "unfair competition," "déloyale" is more accurately translated as "fraudulent" than "unfair," which would suggest a higher threshold. See Christopher Wadlow, The Law of Passing-Off: Unfair Competition by Misrepresentation (3d ed. 2004).

145 G.H.C. Bodenhausen, Guide to the Application of the Paris Convention for the Protection of Industrial Property: As Revised at Stockholm in 1967 (1968). Art. 10bis presently provides the following example of an act of unfair competition: "all acts of such a nature as to create confusion by any means whatever with the establishment, the goods, or the industrial or commercial activities, of a competitor." See International Convention for the Protection of Industrial Property, art. 10bis, Mar. 20, 1883, 828 U.N.T.S. 107, 139. An attempt to remove the restriction of the protection to competitors was defeated at the 1958 Lisbon Conference. Wadlow, supra note 144, at 60.

146 Inter-American Convention, supra note 8, at 2940. 
proclaims that "unless otherwise effectively dealt with under the domestic laws of the Contracting States," acts of unfair competition "shall be repressed under the provisions of this Convention." 147 Furthermore, Article 22 states that "[t]he Contracting States which may not yet have enacted legislation repressing the acts of unfair competition ...., shall apply to such acts the penalties contained in their legislation on trade marks . . . and shall grant relief by way of injunction against the continuance of said acts at the request of any party injured; those causing such injury shall also be answerable in damages to the injured party." 148

These provisions establish that these protections are to be given immediate effect even in the absence of relevant domestic legislation. The protections against unfair competition are thus framed as self-executing. The prohibited acts are sufficiently described in the convention and the remedies provided in existing trademark legislation shall be available. In addition, the convention includes an "answerable in damages" clause. This provision mandates a civil remedy; something not required by the Paris Convention. ${ }^{149}$ The convention was prescient and pragmatic. With the exception of the United States, all of the member states were civil law countries that depend on a code to provide rights.

The convention was thus pioneering beyond articulating new protections against unfair competition. Ladas and Rogers later stated that the protections achieved in the Inter-American Convention were superior to those achieved in the Paris Convention. ${ }^{150}$ It is not surprising that they would have exceeded the Paris Convention protections. The freedom they had to create new protections whole cloth in the Inter-American Convention was unparalleled. They were not constrained by the need to reconcile conflicting legal standards across jurisdictions. They instead were working from a blank slate; the other states had no law of unfair competition. ${ }^{151}$ They were also operating without even the normal constraints in a treaty development since most of the Latin American delegates were diplomats, not trademark experts. In addition, the environment was hospitable to creativity. Previous

147 Id. at 2932 (emphasis added).

148 Id. at 2934.

149 See Wadlow, supra note 144, at 59.

150 Edward S. Rogers \& Stephen P. Ladas, Proposal for Uniform Trademark Laws, 40 TMR 8, 14 (1950) ("It embodies international legislation on trade-marks, trade names, indications of origin, and unfair competition in some respects superior to that achieved by the European International Union foe the Protection of Industrial Property.") (emphasis in original).

151 Id.; see also Ladas, supra note 119, at 52 ("Inasmuch as there has not been a long preparation and continuity of study of these questions in all the American countries, it is reasonable to make use of the experience acquired but other countries in dealing with the same problems."). 
Pan-American Conventions had already served as a creative space for the development of new solutions for trademark owners, such as the creation of a Pan-American trademark registration and priority based on protection in another member state. ${ }^{152}$

The convention provided Rogers unrestricted freedom to draft his ideal set of unfair competition protections and his concern was solely for U.S. traders. Rogers had developed an international perspective on trademark protection and had in mind various ways that U.S. trademarks owners were vulnerable internationally. ${ }^{153} \mathrm{In}$ his book anticipating the 1929 Pan-American Conference, Ladas stated that "[w]hat American manufacturers and traders ... need especially today is . . . a more effective and complete protection." 154

The Inter-American Convention provided Rogers and Ladas with a blank canvas to think big about trademark and unfair competition protections, which contrasted sharply with the domestic legislative environment. There may not, however, have been reason at that time to seriously contemplate the convention's impact on U.S. law. It was unlikely that there would be any plaintiffs hailing from member states that would utilize the convention in U.S. federal courts, and the legal environment in the United States in the 1930s was general inhospitable to the expansion of rights.

Within a decade later, however, two Supreme Court decisions, which will unfold in the next sections, would shift the outlook on the protections contained in the Inter-American Convention. The first was Erie R.R. v. Tompkins, which wiped out all of the then existing common law of unfair competition in 1938. ${ }^{155}$ The second was the Court's decision in Bacardi Corp. of America v. Domenech in 1940, which declared the Inter-American Convention to be self-executing.

\section{The Inter-American Convention Today}

Given its undisputed success and its novelty, it is puzzling that most trademark lawyers today are unfamiliar with the InterAmerican Convention. After all, the convention has neither been superseded nor denounced, but remains valid and in force today in the United States and in every one of the original contracting

152 Convention for the Protection of Commercial, Industrial and Agricultural Trade Marks and Commercial Names, Apr. 28, 1923, 44 Stat. 2494; Convention for the Protection of Trade Marks, Aug. 20, 1910, 39 Stat. 1675; see also Farley, supra note 141, at 64-67.

153 At an international conference in 1930, Rogers described "a prevailing sport" in other countries where "two or three people ... get together and start a company under the name of Coca Cola. Then the Coca Cola firm gets into that country and finds a company under that name already there, with the result that the firm has either to change the name or buy the company." Hanna Katz, An International Aspect of the Pending TradeMark Bill, 35 TMR 146, 148 (1945).

154 Ladas, supra note 119 , at 34.

155 McCarthy, supra note 2, at $\S 27.7$ ("the 1938 Erie Railroad Supreme Court decision, ... it was widely felt, had eliminated the existing body of federal unfair competition law.”). 
states. ${ }^{156}$ It is not as if the United States has not signed so many multilateral trademark treaties that this convention is getting lost in a crowd. ${ }^{157}$ The convention's lack of notoriety would be understandable if its provisions had been reiterated in other international agreements or in the Lanham Act. But this is not the case; the Inter-American Convention provides some of the strongest trademark protections seen in any international agreement to date as well as some fairly radical trademark rights. ${ }^{158}$ Foreign case law suggests that the convention has not been forgotten in member states and has therefore played a very different role abroad. ${ }^{159}$

156 Id. The United States did, however, formally renounce the convention's Protocol on the Inter-American Registration of Trade-marks in 1945. Stephen P. Ladas, The Lanham Act and International Trade, 14 Law \& Contemp. Probs. 269, 271 (1949).

157 The United States is party to only six multilateral agreements on trademark law, and most are much more recent: the Paris Convention; the Inter-American Convention; the Agreement on Trade-Related Aspects of Intellectual Property Rights (the "TRIPS Agreement"); the Trademark Law Treaty; the Singapore Treaty; and the Madrid Protocol. U.S. Dep't of State, Treaties in Force: A List of Treaties and Other International Agreements of the United States in Force on Jan. 1, 2019, 520 (2019).

158 The convention's exceptions to territoriality are inventive and replicated nowhere else. Farley, supra note 141, at 64-67. The convention's protections for geographical indications and against unfair competition are the most sweeping in any agreement to which the United States is a party to date. See Christine Haight Farley, The Protection of Geographical Indications in the Inter-American Convention on Trademarks, 6 WIPO J. 68, 70 (2014); Christine Haight Farley, Looking Beyond the Known Story: How the Prehistory of GI Protection in the Americas Provides an Alternate Approach, in Geographical Indications at the Crossroads of Trade, Development and Culture in AsiaPacific 212, 212-13 (Irene Calboli \& Loy Wee Loon eds., 2017).

159 The convention is still effectively invoked on behalf of U.S. trademark owners in other member states. See, e.g., Colombia: Superintendency of Industry and Commerce of Colombia, Resolution of October 11, 2011 (cancelling Colombian registration for CROSS FIT under the convention based on registration in the U.S.); Superintendency of Industry and Commerce of Colombia, Resolution No. 4328 of February 20, 2001 (cancelling Colombian registration for HAWAIIAN TROPIC under the convention since the mark was previously registered in member state Ecuador and registrant had knowledge); Guatemala: Exclusividades Finas, Sociedad Anónima v. Inversiones San Agustin, Sociedad Anónima, Case 59-94, Supreme Court of Justice (1994) (cancelling Guatemalan registration for OSHKOSH B'GOSH as contravening the convention due to the prior registration by Oshkosh B'Gosh Inc. in the United States); Midas International Corporation v. Jorge Oswaldo Urrutia Lamas, Case 69-95, Supreme Court of Justice (1995) (cancelling Guatemalan registration for MIDAS as contravening the convention due to the existence of prior rights in the United States); Antonio Malouf Gabriel v. Calvin Klein, Supreme Court of Justice (1999) (cancelling Guatemalan registration for CALVIN KLEIN as contravening the Convention based on prior rights in the United States); Nicaragua: Decision No. 94, 10:45 AM, July 12, 1996 (unpublished) (cancelling Nicaraguan registration for SUR under the convention based on prior registration in member state Panama); Panama: Appeal from Resolution No. 106 of December 16, 1993, of the General Directorate of Interior Commerce of the Ministry of Commerce (Supreme Court of Justice, September 9, 1994) (cancelling Panamanian registration for FOOT LOCKER under the convention based on prior U.S. registration for the identical mark for the same goods and the notoriousness of the mark); Saks \& Company v. Saks Zona Libre, S.A., Ministry of Commerce, Resolution 39 of June 2, 1995 (cancelling Panamanian registration for SAKS FIFTH AVENUE under the convention based Saks \& Company's prior registration of the mark in the U.S.); Resolution No. 94, June 8, 1994 (cancelling Panamanian registration for VOGUE under the convention based on prior 
The Inter-American Convention may have been forgotten because, over the years, some ambiguity has arisen as to its force. The specific rights contained in the convention were never codified in the Lanham Act. At first glance, that fact may seem curious since Rogers drafted the Lanham Act and was in the best position to include the convention's provisions. It behooves us then to consider why the convention was not implemented in this manner.

The main reason may be that Rogers understood the convention to be self-executing, meaning that the convention's substantive provisions can be given legal effect in U.S. courts without any action taken by the legislature to make the treaty operative. ${ }^{160}$ The case for the convention being self-executing is strong. ${ }^{161}$ First, it does not contain language indicating that it is not self-executing, as some treaties do. On the contrary, the convention states that "The provisions of the Convention shall have the force of law in those States in which international treaties possess that character, as soon as they are ratified by their constitutional organs." 162 Moreover, in most instances, such as the provisions on unfair competition, the rights are so specific and detailed that direct judicial application is enabled without the need of implementing legislation. ${ }^{163}$

The most powerful argument that the treaty is self-executing, however, is that the Supreme Court has so held. In Bacardi Corp. of America v. Domenech, in a unanimous opinion, the Court held that "[t]his treaty on ratification became a part of our law. No special legislation in the United States was necessary to make it effective." 164

registration in member state Colombia); Resolution No. 147, August 9, 1994 (cancelling Panamanian registration for LAMBORGHINI under the convention based on prior registration in the United States); Resolution No. 147, August 9, 1994 (cancelling Panamanian registration for CREAMETTE under the convention based on prior registration in the United States); Resolution No. 147, August 9, 1994 (cancelling Panamanian registration for JAGUAR under the convention based on prior registration in the United States); Resolution No. 69, April 20, 1994 (cancelling Panamanian registration for GAP under the convention based on prior registration in the United States).

160 See Medellín v. Texas, 552 U.S. 491, 505 n.2 (2008) ("What we mean by 'self-executing' is that the treaty has automatic domestic effect upon ratification. Conversely, a 'non-selfexecuting' treaty does not by itself give rise to domestically enforceable federal law.”).

161 The purpose here is not to demonstrate that the treaty is self-executing and would be so recognized by a court today, but instead to demonstrate that Rogers would have been convinced that the treat was self-executing in 1946.

162 See Inter-American Convention, supra note 8, at 2941 (art. 35).

163 Courts have rejected claims by foreign parties asserting rights under the Paris Convention's unfair competition provisions. See, e.g., Mattel, Inc. v. MCA Records, 296 F.3d 894, 908 (9th Cir. 2002); Gen. Motors Corp. v. Ignacio Lopez De Arriortua, 948 F. Supp. 684, 688 (E.D. Mich. 1996).

$164 \quad 311$ U.S. $150,162-163$ (1940). 
The drafter of the Lanham Act would have been the most familiar with the Bacardi case. He both briefed and argued the case before the Supreme Court. ${ }^{165}$ In fact it was he who suggested to the Court, and ultimately convinced it, that the Inter-American Convention was self-executing. ${ }^{166}$ If there was ever any doubt in his mind that the convention would not be accepted by the courts as self-executing, the Supreme Court laid that doubt to rest in 1940, just six years prior to the enactment of the Lanham Act.

The self-executing status of the treaty may in part explain why its protections were not explicitly included in Rogers's draft of the Lanham Act. Although anomalous today, it is important to remember that our expectation that treaties be implemented by legislation is of a fairly recent origin. Self-executing treaties fell into disfavor in the years just following enactment of the Lanham Act. ${ }^{167}$ In 1929, therefore, Rogers's expectation that the treaty would be self-executing would have been sound.

\section{THE DEATH OF COMMON LAW UNFAIR COMPETITION}

It would be difficult to overstate the importance of the common law to trademark and unfair competition law before the 1946 Lanham Act. Because under the 1905 Trademark Act only the owners of technical trademarks were granted rights, which were highly constrained, ${ }^{168}$ any other rights were governed exclusively by common law. ${ }^{169}$ Although unfair competition cases could not be

$165 \quad I d$.

166 In the petitioner's brief, he stated: "No special legislation implementing this treaty is necessary in the United States" Brief for Petitioner at 26, Bacardi Corp. of America v. Domenech, 311 U.S. 150 (1940) (No. 21).

167 Restatement, Third, Foreign Relations Law of the United States (Revised) 56 (1987) ("Self-executing treaties were contemplated by the Constitution and have been common. They avoid delay in carrying out the obligations of the United States. They eliminate the need for participation by the House of Representatives (which the Framers of the Constitution had excluded from the treaty process), and for going to the Senate a second time for implementing legislation after the Senate had already consented to the treaty by two-thirds vote."). The attitudinal shift on self-execution occurred around 1952 in response to a case in which the legality of the wartime internment of Japanese Americans was challenged under the United Nations Charter, whose obligations were argued to be self-executing. See Sei Fujii v. State of California, 38 Cal. 2d 718, 722 (1952). The case provoked the so-called "Bricker Amendments" proposed by conservative Members of Congress that would require Congressional approval of all self-executing treaties. David L. Sloss, The Death of Treaty Supremacy: An Invisible Constitutional Change 237-38 (2016). The amendments failed (by a single vote), but the Senate debates helped "solidify a consensus within the federal political branches supporting [a non-selfexecuting] exception to the treaty supremacy rule." Id. at 231. The attitude toward selfexecuting treaties was changed for good.

168 Act of Feb. 20, 1905, ch. 592, 33 Stat. 724, 728.

169 Bartholomew Diggins, Federal and State Regulation of Trade-Marks, Law \& Contemp. Prob. 200, 202 (1949). 
heard in federal court unless there was diversity jurisdiction, this was increasingly the case as commerce expanded. ${ }^{170}$ In both trademark and unfair competition cases heard in federal courts, judges typically paid only "lip-service to the rule that substantive rights in trade-marks rested upon the laws of the several states." 171 As a result, "a great body of federal law was built up with no apparent regard for state precedents." 172 In contrast, "the common law of the states was uncertain and unsatisfactory, largely because of the scarcity of precedents." 173 Consequently, unfair competition law was governed almost exclusively by federal common law. ${ }^{174}$

The landmark decision in 1938 in Erie R.R. v. Tompkins ${ }^{175}$ thus had major implications for trademark and unfair competition law. Ruling that "[t]here is no federal general common law," 176 the Supreme Court overturned decades of federal common law. The impact of Erie for trademark and unfair competition law was not merely, as in other areas of law, that several pre-1938 decisions lost their precedential significance. Rather, in trademark law, the Erie doctrine potentially left an utter void. 177

A coincidence may have initially blunted the blow of Erie for unfair competition law. Less than seven months after issuing the decision in Erie, the Supreme Court decided an important unfair competition case: Kellogg Co. v. National Biscuit Co. ${ }^{178}$ Notably, Justice Brandeis, who authored the majority opinion in Erie, also wrote the majority opinion in Kellogg. Adding further significance to the cast of characters, Rogers represented Kellogg, the defendantpetitioner in the case. Surprisingly, the 159-page brief filed in

$170 \quad I d$.

$171 \quad I d$.

$172 I d$.

173 Id. at 201; see also Rogers, New Concepts of Unfair Competition under the Lanham Act, supra note 103, at 259 ("It was frequently found that there were no applicable State decisions or that the decisions in the States comprising the same circuit were not uniform.").

174 Sergei S. Zlinkoff, Erie v. Tompkins: In Relation to the Law of Trade-Marks and Unfair Competition, 42 Colum. L. Rev. 955, 960-61 (1942) ("In the domain of trade-marks and unfair competition, the loss of this important body of decisional law will be keener and greater than is likely to occur in most other fields, due to the fact that the federal courts have been the usual forum for such litigation.”).

175304 U.S. 64 (1938).

$176 \quad$ Id. at 78 .

177 Philco Corporation v. Phillips Mfg. Co., 133 F.2d 663, 666 (7th Cir. 1943) ("there has been a federal general common law and cases have been 'governed by federal law' within the meaning of the Erie doctrine, for federal courts have exercised independent judgment as to what 'the common law' was in all cases in the field.") (emphasis added); Rogers, New Concepts of Unfair Competition Under the Lanham Act, supra note 103, at 259 ("there was chaos").

178305 U. S. 111 (1938). The Supreme Court decided Erie v. Tompkins on April 25, 1938, and Kellogg Co. v. National Biscuit Co. on November 14, 1938. 
September of 1938 on behalf of Kellogg never mentions the five month-old Erie decision nor does it attack the lower court's ruling for relying on federal common law. ${ }^{179}$ Justice Brandeis, however, did explicitly address the impact of the Court's ruling in Erie in the first footnote of the majority opinion, stating that " $[\mathrm{m}]$ ost of the issues in the case involve questions of common law and hence are within the scope of Erie R. Co. v. Tompkins, 304 U.S. 64 (1938). But no claim has been made that the local law is any different from the general law on the subject, and both parties have relied almost entirely on federal precedents." 180

As the case had by then been litigated for a decade, ${ }^{181}$ it would have been late in the case to reconceive it under state law, especially with such short notice. But because there was no "local law" to rely on-at least in the pleadings, the theory of the case did not need to be altered. The reasoning in the Kellogg Court's first footnote thus provided a large loophole to avoid the Erie doctrine in unfair competition cases, and the Erie doctrine would appear to have lost some of its thrust in this area within a year.

Another coincidence: a mere three weeks after the Kellogg decision, the Supreme Court decided yet another unfair competition case, ${ }^{182}$ and again Rogers was involved, this time representing the plaintiff-respondent. Remarkably, seven and a half months after ruling in Erie that federal courts are required to apply the law of the state in which they sit, the Court again reached its decision relying only on federal common law. ${ }^{183}$ Significantly, the Court decided that the invalidity of a trademark registration does not divest a federal court of its jurisdiction over a claim of unfair competition. In doing so, the Court opened an avenue for greater jurisdiction over unfair competition cases. ${ }^{184} \mathrm{~A}$ federal court having jurisdiction over an unfair competition claim, however, does not settle the question of what law controls. The Court went on to state that "[t]he remedy for unfair competition is that given by the common law," 185 relying exclusively on its opinion in a 1901 decision. ${ }^{186}$ Thus, within a year

179 Brief for Petitioner at 1, Kellogg Co. v. National Biscuit Co., 305 U.S. 111 (1938).

180305 U.S. at 113 n.1.

181 See Shredded Wheat Co. v. Kellogg Co., 26 F.2d 284 (D. Conn. 1928).

182 Armstrong Paint \& Varnish Works v. NuEnamel Corp. 305 U. S. 315 (1938) (decided on December 5, 1938).

183 Diggins, supra note 169, at 204 (stating that the Court failed to "cite a single state decision [or] refer to state law").

184305 U. S. at 319 ("[i]f it is not a properly registered trade-mark, the ground is unfair competition at common law. The facts supporting a suit for infringement and one for unfair competition are substantially the same. They constitute and make plain the wrong complained of, the violation of the right to exclusive use."). 
of its Erie decision, the Court enunciates the basis of an unfair competition claim relying entirely on federal common law.

Such opinions, however, belie the extent to which the law of unfair competition was on unstable ground following Erie. The impact of Erie set in gradually. For instance, eight months after Kellogg, the Seventh Circuit decided an unfair competition case ${ }^{187}$ "without reference to Illinois law . . basing its decision exclusively upon decisions of the federal courts." 188 Two years later, however, that same court, relying on Erie, reversed the district's ruling in favor of the plaintiff's unfair competition claim, ${ }^{189}$ and criticized the district court for "decid[ing] the case upon general Federal law." 190 It may have taken this long for the defense bar to realize the potential of Erie. ${ }^{191}$

Such decisions would have sent shockwaves through the trademark bar. ${ }^{192}$ At best, after 1938, trademark and unfair competition cases faced the difficult hurdle maintaining their reliance on the substantive rights offered by federal law. ${ }^{193}$ The Second Circuit nicely summed up the state of the law at that time:

Until the advent of Erie R. Co. v. Tompkins, ... federal law was accepted as controlling issues of both trademark infringement and unfair competition. But since the advent of the energetic doctrine which takes its name from that case the situation has been confused. Some vigorous judicial claims are still heard for a uniform law; but the major view at least nods in the direction of a state rule, usually hazy, before resorting to the more complete and pertinent federal precedents. ${ }^{194}$

If trademark owners were required to find their cause of action and remedy under state law alone, they would be left wanting. Post1938, therefore, there was a strong sense among trademark practitioners that both state and federal rights in trademark and

187 Sinko v. Snow-Craggs Corp., 105 F.2d 450 (7th Cir. 1939).

188 Diggins, supra note 169, at 204.

189 Addressograph-Multigraph Corp. v. Am. Expansion Bolt \& Mfg. Co., 124 F.2d 706 (7th Cir. 1942).

$190 \quad I d$. at 708.

191 The Seventh Circuit admonished the district court for not considering the "defendant's contention that under Erie R. Co. v. Tompkins ... the law of the state, as announced by its courts, must be given effect." Id. The court then proceeded to rule that under state law, actionable unfair competition was limited to passing off and that a claim for the misappropriation of a business system could not succeed. Id.

192 Chafee, supra note 21, at 1299 ("This valuable body of law is now likely to be torn into pieces because of the Tompkins case.").

193 As late as 1980, the Ninth Circuit announced in a trademark case: "Save as an outgrowth of federal statutory or constitutional law, there is no federal common law." Int'l Order of Job's Daughters v. Lindeburg \& Co., 633 F.2d 912, 915 (9th Cir. 1980).

194 Dad's Root Beer Co. v. Doc's Bevs., 193 F.2d 77, 80 (2d Cir. 1951). 
unfair competition was "woefully inadequate." 195 Not only were federal common law rights in flux, but federal trademark legislation had never offered much protection to traders. Rogers's congressional testimony summed up the sentiment of the trademark bar: "we now have a rather confused situation which is difficult to understand . . . it is hard for anyone to find out what the Federal statutory law is, because it is so badly scattered." 196 It had long been the consensus of the trademark bar that trademark law was due for an overhaul. ${ }^{197}$

\section{THE 1946 LANHAM ACT}

The trademark bar was dissatisfied with 1905 and 1920 trademark acts almost as soon as they were enacted, and frustration only increased over the decades before the passage of the Lanham Act in 1946. ${ }^{198}$ The push for a revised trademark act was fueled by the belief that the existing laws put U.S. trademark owners at a disadvantage internationally because of the significant hurdles they faced obtaining a registration. 199

The origins of the 1946 Lanham Act date as far back as 1921 when Rogers debuted his first draft. 200 These efforts stalled until 1938 when the first of the bills by Congressman Fritz Lanham, for whom the act was named, were introduced. ${ }^{201}$

195 Diggins, supra note 169, at 203.

196 Hearings on H.R. 4744 Before the Subcomm. on Trade-Marks of the House Comm. on Patents, 76th Cong., 1st Sess. 167 (1939) [hereinafter Hearings on H.R. 4744] (Statement by Rogers).

197 Diggins, supra note 169, at 210.

198 Edward S. Rogers, Some Suggestions Concerning a Trade-Mark Registration Act, 43rd Conf. Ann. Rep. A.B.A. 398, 414 (1920) ("No one, I think, will dispute the assertion that our present act, like its predecessors, is a slovenly piece of legislation, characterized by awkward phraseology, bad grammar and involved sentences. Its draftsmen had a talent for obscurity amounting to genius.").

199 Report of the Forty-Third Annual Meeting of the American Bar Association 412-22 (1920).

200 Rogers's 1924 draft was the first to become a bill. See S. 2679, 68th Cong. (1st Sess. 1924). Derenberg states that the 1924 draft was "the continuation of trademark law revision efforts which began as far back as the year 1920" and "the real origin of much of what was subsequently included in the Act of 1946 derives from a now famous address by Edward S. Rogers before the American Bar Association in 1921.” Derenberg, supra note 105 , at 189 .

201 H.R. 9041, 75th Cong. (1st Sess. 1938). After Rep. Lanham introduced H.R. 9041, six subsequent bills were considered before H.R. 1654 was finally passed. See H.R. 4744, 76th Cong. (1st Sess. 1939), reprinted in Trade-Marks: Hearings on H.R. 4744 Before the Subcomm. on Trade-Marks of the House Comm. on Patents, 76th Cong. (1st Sess. 1 1939); H.R. 6618, 76th Cong. (1st Sess. 1939), reprinted in Patents and Trade-Marks: Hearings on H.R. 6618 Before the House Comm. on Patents, 76th Cong. (1st Sess. 1 1939); H.R. 102, 77th Cong. (1st Sess. 1941), reprinted in Trade-Marks: Hearings on H.R. 102, H.R. 5461, and S. 895 Before the Subcomm. on Trade-Marks of the House Comm. on Patents, 77th Cong. (1st Sess. 2 1941); S. 895, 77th Cong. (1st Sess. 1941), reprinted in House Hearings on H.R. 102, H.R. 5461, and S. 895; H.R. 5461, 77th Cong. (1st Sess. 1941), reprinted in House Hearings on H.R. 102, H.R. 5461, and S. 895, at 14; H.R. 82, 78th Cong. (1st Sess. 1943), reprinted in Trade-Marks: Hearings on H.R. 82 Before the House 
In 1949, in a case handled by Rogers's firm, Judge Learned Hand notes the Lanham Act's success in rectifying the former issues in federal trademark law. Judge Hand declares that the Lanham Act "did indeed put federal trade-mark law upon a new footing" as "it is no longer open to doubt that the present act created rights uniform throughout the Union." ${ }^{202} \mathrm{He}$ then, however, rather portentously continued, "[c]learly a change, and a most substantial change, was intended, and the question is what that was." 203

As to what Congress did intend to change, one could look to the act itself where Congress is uncharacteristically explicit in its legislative objective:

The intent of this Act is to regulate commerce within the control of Congress by making actionable the deceptive and misleading use of marks in such commerce; to protect registered marks used in such commerce from interference by State, or territorial legislation; to protect persons engaged in such commerce against unfair competition; to prevent fraud and deception in such commerce by the use of reproductions, copies, counterfeits, or colorable imitations of registered marks; and to provide rights and remedies stipulated by treaties and conventions respecting trademarks, trade names and unfair competition entered into between the United States and foreign nations. ${ }^{204}$

This language is unambiguous: Among other things, Congress both intended to offer unfair competition protection and to effectuate treaty rights. Congress's intent thus mirrored Rogers's. Curiously, however, Rogers's approach seems to have been to achieve both objectives indirectly rather than directly. ${ }^{205}$

Today, we accept that unfair competition protection is provided in Section 43(a) of the Lanham Act. Contrary to contemporary understanding, however, the legislative history of the Lanham Act reveals that neither Rogers nor Congress intended for Section 43(a) to be the vehicle for federal unfair competition protection in the Lanham Act. Instead, Rogers intended for Section 44-his brainchild - to provide federal unfair competition protection.

Comm. on Patents, 78th Cong. (1st Sess. 1943). Activity on the bill was stalled until after World War II and was finally passed on July 5, 1946. McCarthy, supra note 2, at § 5:4. S.C. Johnson \& Son v. Johnson, 175 F.2d 176, 178 (2d Cir.), cert. denied, 338 U.S. 860 (1949).

$203 \quad 175$ F.2d at 178.

204 Trademark (Lanham) Act of 1946, Pub. L. No. 79-489, § 45, 60 Stat. 427, 444 (emphasis added).

205 Ladas, supra note 104, at 1702. 
The phrase "unfair competition" appears only twice in the act: In addition to the intent clause quoted above, ${ }^{206}$ it appears in Section 44(h). Therefore, in both places where the phrase appears, it is connected to treaty rights. Section 44 was included in the act to incorporate by reference the stipulations of certain provisions of the Paris Convention and the Inter-American Convention. ${ }^{207}$ The 1946 text of Section 44(b) mentioned both by name, although a 1962 housekeeping revision has since replaced the direct references to these treaties with the generalized "any convention or treaty relating to trademarks." 208

Section 44(h) provides that certain foreign nationals 209 "shall be entitled to effective protection against unfair competition, and the remedies provided ... for infringement of marks shall be available ... in repressing acts of unfair competition." 210 In addition, Section $44(\mathrm{~g})$ provides that the "trade names" of such foreign nationals "shall be protected without the obligation of filing or registration whether or not they form parts of marks." Finally, Section 44(i) extends these "same benefits" beyond treaty beneficiaries to "citizens or residents of the United States." 211

In Section 45, Congress states its intent to "provide rights and remedies stipulated by treaties and conventions respecting trademarks, trade names, and unfair competition entered into between the United States and foreign nations." Lanham Act $§ 45,15$ U.S.C. $\S 1127$.

207 Ladas, supra note 104, at 1702 n.119.

208 See Act of Oct. 9, 1962, Pub. L. No. 87-772, § 20, 76 Stat. 769, 774. Nevertheless, the meaning remains unchanged.

209 See Trademark Act of 1946, § 44(b), 60 Stat. 427, 442 ("Persons who are nationals of, domiciled in, or have a bona fide and effective business or commercial establishment in any foreign country, which is a party to (1) the International Convention for the Protection of Industrial Property, signed at Paris on March 20, 1883; or (2) the General Inter-American Convention for Trade Mark and Commercial Protection signed at Washington on February 20, 1929; or (3) any other convention or treaty relating to trademarks, trade or commercial names, or the repression of unfair competition to which the United States is a party, shall be entitled to the benefits and subject to the provisions of this Act to the extent and under the conditions essential to give effect to any such conventions and treaties so long as the United States shall continue to be a party thereto, except as provided in the following paragraphs of this section.").

210 Lanham Act $\S 44(\mathrm{~h}), 15$ U.S.C. $\S 1126(\mathrm{~h})$ (“Any person designated in paragraph (b) of this section as entitled to the benefits and subject to the provision of this Act shall be entitled to effective protection against unfair competition, and the remedies provided herein for infringement of marks shall be available so far as they may be appropriate in repressing acts of unfair competition."). Initially, that subsection read, "All acts of unfair competition in commerce are declared to be unlawful and the provisions of section 32 to 35 inclusive shall be applcable [sic] thereto." Hearings on H.R. 4744, supra note 196, at 163.

211 Lanham Act $§ 44(\mathrm{i}), 15$ U.S.C. $§ 1126$ (i) ("Citizens or residents of the United States shall have the same benefits as are granted by this section to persons described in paragraph (b) hereof."). 


\section{A. Legislative History Lessons}

An earlier iteration of the provision that ultimately was enacted as subsection 44(h) boldly stated "All acts of unfair competition in commerce are declared to be unlawful and the provisions of sections 32 to 35 inclusive shall be applicable thereto." 212 Although this subsection appeared in "Title IX-International Conventions," it was not otherwise hinged to treaty beneficiaries.

In a 1939 hearing on the bill that contained that language, three trademark practitioners appearing as witnesses-Thomson, Byerly, and Luce- each expressed concern over the breadth of claims that would be enabled by this provision. Thomson noted that this subsection "covers a very wide field, and its construction has given jurisdiction to the Federal courts in any case involving unfair competition." 213

Rogers, also a witness, but seemingly one holding court, defended the provision by arguing that our treaty obligations required it. He stated that " $[\mathrm{b}] \mathrm{y}$ all the conventions we undertake to grant the foreigners effective protection against unfair competition. The foreigner says, 'What have you given us?' . . . Then you talk to a foreigner about the common law, and he says, 'What is that? We haven't any such thing in our country.' And then we try to explain that there are 48 varieties of common law in the United States, and he says, "Which one is the one that I am entitled to be protected under? There is no Federal statute that helps me." 214 He stated the consequence was that "because we haven't put it in some kind of Federal statute ..., our people are being refused protection abroad because there is no reciprocity." 215

This legislative history reveals the relationship of Sections 44 and 43(a). The provision that ultimately became Section 43(a) was initially more limited. Its enlargement occurred only as a result of a suggestion offered by one of these witnesses not intended to enlarge unfair competition protection, but to restrict it. The suggestion was made because the witness was concerned that Rogers's unfair competition provision was "dangerously broad." 216

The witness Byerly suggested that the provision that ultimately became Section 43(a) was the more appropriate place to deal with unfair competition. ${ }^{217}$ He suggested making the protections clearer in that section rather than adding confusion with "this rather vague section [44(h)] which has been put in later, which apparently does

212 See H.R. 4744, 76th Cong. § 45(g) (1939).

213 Hearings on H.R. 4744, supra note 196, at 164 (Statement by Thomson).

214 Id. (Statement by Rogers).

215 Id.

216 See Hearings on H.R. 4744, supra note 196, at 167 (Statement by Byerly).

$217 I d$. at 165 (Statement by Byerly). 
not require you to have registration, and therefore it is difficult to see how you have any Federal law at all."218 Byerly's proposal was that the act simply state a cause of action for passing off available to trademark registrants. ${ }^{219} \mathrm{His}$ comments evidence an exceedingly narrow conception of unfair competition, but Rogers did not contest it. Curiously, Rogers stated that "Mr. Byerly has drafted an admirable definition of unfair competition." 220 He went on, however, to state that "unfair competition is what Louis [sic] Carroll used to like to call a 'portmanteau' word-it means a lot of things, and it means different things to different people, and the minute you attempt to define it you limit it." 221 Byerly proposed that then Section 32 include a claim for "any person who falsely indicates to the public that any goods or articles are the goods of the registrant," indicating his belief that such a provision "covers unfair competition at least in the ordinary sense of the word, which is passing off your goods for those of others." 222 Crystallizing his fundamental divergence with Rogers, he stated, "I think we could very plausibly tell our foreign friends that " $\mathrm{t}]$ his is what we consider unfair competition." 223

Rogers's argument for retaining the provision that became Section 44(h) was two-pronged. First, he argued that the United States has already obligated itself to provide foreigners with effective protection against unfair competition. The legislative objective with regard to these obligations is merely to provide a place in the act to point to that indicates implementation of these

$218 \quad I d$.

219 The predecessor to the section Byerly revised, was section 3 of the 1920 Act. That section had required proof of willfulness and an intent to deceive:

SEC. 3. That any person who shall willfully and with intent to deceive, affix, apply, or annex, or use in connection with any article or articles of merchandise, or any container or containers of the same, a false designation of origin, including words or other symbols, tending to falsely identify the origin of the merchandise, and shall then cause such merchandise to enter into interstate or foreign commerce, and any person who shall knowingly cause or procure the same to be transported in interstate or foreign commerce or commerce with Indian tribes, or shall knowingly deliver the same to any carrier to be so transported shall be liable to an action at law for damages and to an action in equity for an injunction, at the suit of any person, firm, or corporation doing business in the locality falsely indicated as that of origin, or in the region in which said locality is situated, or at the suit of any association of such persons, firms, or corporations.

Trademark Act of 1920, ch. 104, § 3, 41 Stat. 533, 534.

See Hearings on H.R. 4744, supra note 196, at 164 (Statement by Rogers).

Id.

$I d$. at 165 (Statement by Byerly).

Id. Possibly disingenuously, Rogers later stated that "[s]ome of our conventions are along the exact lines .... The Inter-American Convention is that kind; that is, it prohibits unfair competition with respect to the marking of goods." Id. at 164 (Statement by Rogers). 
treaty obligations. ${ }^{224}$ Second, since foreigners already enjoy this protection, U.S. citizens should be treated with parity. ${ }^{225}$ Byerly's stated concern that the bill makes "every act of unfair competition ... illegal and [creates] a right of action in the Federal courts for it, without in any way defining it or tying it up to registration" 226 was ignored.

Although Rogers did not yield on his position on unfair competition in the hearing, the statement "All acts of unfair competition in commerce are declared to be unlawful" was quietly replaced in the next text with language that more closely resembles today's Section 44(h). ${ }^{227}$ In addition, Byerly's proposed language accepted as well. Thus, in classic legislative fashion, the Lanham Act ended up with both provisions. This legislative compromise is partly responsible for the uncertainty over the location of unfair competition in the Lanham Act, and is emblematic of the schism between the narrow and expansive views of unfair competition. The provision that ultimately became Section 43(a) was therefore only a result of push-back against the provision that became Section 44(h).

\section{B. The Intent of Section 44}

The legislative history here recounted reveals numerous explicit statements about the act's objectives to import treaty provisions on unfair competition into U.S. law. In these hearings, Rogers made clear the import of Section 44 in his soliloquies on how this provision carried out the nation's obligations under the Inter-American Convention. ${ }^{228}$ In 1939, Rogers assured Congress that "everything

224 See Hearings on H.R. 4744, supra note 196, at 166, 168 ("we have got [unfair competition protection] in the convention, and our friends are criticizing us because we say it is in the convention, and we have not implemented that convention.... so that [if] we [could] point to a section that implements the convention, why we would have accomplished what we need to do with our Latin-American friends who are pretty critical of us.") (Statement by Rogers). That the Inter-American Convention was self-executing and therefore unnecessary to implement was confirmed the Supreme Court the year after this hearing. In any event, Rogers bases the desirability of implementation on the positive diplomatic benefits, not the substantive legal benefits. At the time, there was no consensus on self-executing status of the Paris Convention whose unfair competition protections were less extensive. Ladas thought that certain provisions of the Paris Convention were self-executing. Ladas, supra note 121, at 804 ("[The Paris Convention contains] an important number of provisions [that] constitute common legislation for all member countries and need no municipal law to carry them into effect.").

225 See Hearings on H.R. 4744, supra note 196, at 166 ("The Convention provides that we will give to foreigners, signatories of the convention, effective protection.") (Statement by Rogers).

226 Hearings on H.R. 4744, supra note 196, at 164 (Statement by Thomson).

227 Compare H.R. 4744, supra note 212, with H.R. 6618, id.

228 Treatise author, Rudolf Callmann, stated that the legislative history demonstrates that Congress was fully aware of the implication of Section 44. See Rudolf Callmann, False Advertising as a Competitive Tort, 38 TMR 1048, 1057-58 (1948) ("It is a wholly justifiable inference that the term 'unfair competition,' used in a section designed 'to 
... we are obligated to do in our [Inter-American] Convention is included in this title." 229 Speaking specifically to what would become Section 44(i), Rogers explained that "[w]e have the curious anomaly of this Government giving by treaty and by law with respect to trade-marks and unfair competition to nationals of foreign governments greater rights than it gives to its own citizens .... This is an attempt to put the citizen on an equality with the foreigner" 230 by extending the treaty rights to U.S. citizens.

It is Congress's intent, of course, and not Rogers's that matters. ${ }^{231}$ Still, according to Ladas, "the evidence is overwhelming that the object of Congress was to effectuate the stipulations of the Conventions." 232 The Lanham Act supports Ladas's claim, in two places: In addition to the intent clause in Section $45,{ }^{233}$ the title of the act explicitly professes that its purpose is, inter alia, "to carry out the provisions of certain International Conventions." 234

Another provision in the act also supports the contention that Section 44 states a federal cause of action for unfair competition. Section 39 conferred jurisdiction on the federal courts of "all actions arising under this Act, without regard to the amount in controversy or to diversity or lack of diversity of the citizenship of the parties." 235 Federal jurisdiction thus depends not on whether the plaintiff's mark is registered, as had previously been the case, but instead on whether the action "arises under" the Lanham Act. ${ }^{236}$ That is, a plaintiff need only point to a section of the Lanham Act under which

provide rights and remedies stipulated by treaties and conventions respecting . . . unfair competition' was intended by the draftsmen in its broader sense, as it is used in such treaties and conventions. The Congressional Hearings furnish sufficient proof that the legislators were fully cognizant of the implication of that usage and its interpretation.") (citations omitted).

sis

Hearings on H.R. 4744, supra note 196, at 164.

$I d$. Lanham followed this statement by exclaiming, "I dare say we will find no objection to that." $I d$.

See Johnson \& Son v. Johnson, 175 F.2d 176, 180 (2d Cir.), cert. denied, 338 U.S. 860 (1949) (Clark, J. dissenting) ("the [Lanham] Act is rather clearly the expression of . . . views vigorously held by persons and groups who were able to exercise a persuasive influence in the halls of Congress during its long period of germination").

232 Stephen P. Ladas, Trade-Marks and Foreign Trade, 38 TMR 278, 288-89 (1948) ("It was indeed the intention of those who labored on this Act, as well of Congress, to do as complete a job as possible in carrying out the stipulations of the International Convention to which the United States has become a party.”).

Lanham Act § 45, 15 U.S.C. § 1127.

60 Stat. $427,427$.

Lanham Act § 39, 15 U.S.C. § 1121 ("SEC. 39. The district and territorial courts of the United States shall have original jurisdiction ... of all actions arising under this Act, without regard to the amount in controversy or to diversity or lack of diversity of the citizenship of the parties.”).

236 See Cal. Apparel Creators v. Wieder of Cal., 162 F.2d 893, 900 n.12 (2d Cir.), cert. denied, 332 U.S. 816 (1947); Callmann, supra note 82, at 886; Charles Bunn, The National Law of Unfair Competition, 62 Harv. L. Rev. 987, 998 (1949). 
the action arose and this would now constitute an independent ground for federal jurisdiction.

Any action arising under Section 44 was "under this Act" and therefore within the jurisdiction of the federal courts under Section 39. As one contemporary commentator opined, "[n]ot only do the words of Sections 39 and $44(\mathrm{~g})$, (h) and (i) require this construction, but any other construction would do violence to the intent of Congress stated in Section 45." 237 Ladas was in agreement with Rogers as to "the significance of sub-sections (h) and (i) of Section 44 from the point of view of unfair competition law enforceable by the Federal Courts" was that "these provisions ... changed the situation created by the Erie Railroad $v$. Tompkins case." 238

On the direct operability of the Inter-American Convention in federal courts Ladas argued that "[o]ur constitutional rule is clear that treaties and Acts of Congress ... are equally the supreme law of the land and the Courts are bound to enforce them .... [I]f there is a clear conflict between an earlier treaty and a subsequent statute, it is the statute that prevails. However, the Courts have said that a clear intent of Congress to 'abrogate' the treaty is required for the Courts to disregard a treaty stipulation. There is otherwise a presumption against the existence of a conflict between provisions of a statute and stipulations of a treaty." ${ }^{339}$ Even were that not so, he added, "[a]ny doubt as to this may now be deemed to have been set at rest by the decision of the Supreme Court in Bacardi." 240

Rogers's understanding that Section 44 provided federal unfair competition rights in the Lanham Act is supported by his writings. In 1945-a year before the Lanham Act's enactment-Rogers published an article titled "Unfair Competition," in which he posed the question, "Have the Industrial Property Treaties Given Us a

Diggins, supra note 169, at 207-08 ("Section 45 states that Congress intended to make 'actionable the deceptive and misleading use of marks in ... commerce; to protect persons engaged in ... commerce against unfair competition; ... and to provide rights and remedies ... respecting trade-marks, trade names and unfair competition....'The only place in which such conduct is made actionable and such protection, rights, and remedies are afforded in the case of unfair competition not involving registered marks is in Section 44, so that Congress must have intended that such cases should be actions arising under the Lanham Act and within the jurisdiction of the federal courts under Section 39.").

238 Ladas, supra note 232, at 288; see also Daphne Robert, The New Trade-Mark Manual 177 (1947) ("It is clearly apparent that an action for unfair competition is an action 'arising under the Act,' and therefore jurisdiction is in the Federal Courts, irrespective of diversity or lack of diversity of citizenship. The new Act makes an action for unfair competition relief a statutory right of action and protection will be granted under the Federal law and not limited to the common law of the States."). 
Code?" 241 Unsurprisingly, Rogers answers this question in the affirmative. The article was an opportunity for him to explain to the trademark bar how the Paris and the Inter-American conventions provided a federal law of unfair competition. In another article published a year after the Lanham Act became effective, Rogers made a small, but significant, revision to his question: "Have the Industrial Property Treaties and the New Trade-Mark Act Given Us a National Code of Unfair Competition?" ${ }^{42}$ Here he unequivocally states his position as the chief drafter of the Lanham Act that Section 44 of the Lanham Act is to be read in conjunction with the treaties to provide a general federal law of unfair competition. ${ }^{243}$

Did Rogers successfully create a federal code of unfair competition protection through this circuitous route? A fundamental rule of statutory interpretation is that statutes should be construed "so as to avoid rendering superfluous" any statutory language. ${ }^{244}$ Therefore, Section 44 must be read in such a way as to give it meaning that is not elsewhere stated in the act. As a result of the principle of national treatment contained not only in the Inter-American Convention, ${ }^{245}$ but also the Paris Convention ${ }^{246}$ and now the Agreement on Trade-Related Aspects of Intellectual Property Rights, ${ }^{247}$ all beneficiaries included in Section 44(b) would be protected by Section 43(a) and would have access to federal court to sue under this section. Section 44(b) grants to certain beneficiaries additional treaty rights where those treaty rights are more extensive than the Lanham Act otherwise provides. Thus,

241 Rogers, supra note 32, at 131.

242 Rogers, New Concepts of Unfair Competition under the Lanham Act, supra note 103, at 264.

243 This view is supported by a commentator: "we now apparently have a law defining Unfair Competition, in one aspect made in pursuance of a treaty which constitutes the supreme law of the land. Specifically it applies to citizens of the United States as well as to foreign nationals . . . it is urged that by Federal statutory law, applicable to all citizens engaged in commerce within the control of Congress." Arthur A. March, Unfair Competition Defined, 37 TMR 731, 737 (1947).

244 Corley v. U.S., 556 U.S. 303, 314 (2009) ("a statute should be read, if possible, so that all of its provisions are given effect and none is superfluous"); TRW Inc. v. Andrews, 534 U.S. 19, 31 (2001) ("[A] cardinal principle of statutory construction that a statute ought, upon the whole, to be so construed that, if it can be prevented, no clause, sentence, or word shall be superfluous, void, or insignificant.") (quoting Duncan v. Walker, 533 U.S. 167, 174 (2001)); Astoria Federal Savings \& Loan Ass'n v. Solimino, 501 U.S. 104, 112 (1991); D. Ginsberg \& Sons v. Popkin, 235 U.S. 204, 208 (1932) ("The construction contended for would violate the cardinal rule that, if possible, effect shall be given to every clause and part of a statute.").

245 See Inter-American Convention, supra note 8, at 2919 (art. 1).

246 See Paris Convention for the Protection of Industrial Property, art. 2, Mar. 20, 1883, 828 U.N.T.S. 107, 115.

247 The TRIPS Agreement, art. 3, Apr. 15, 1994, Marrakesh Agreement Establishing the World Trade Organization, Annex IC, Results of the Uruguay Round, 33 I.L.M. 1125, 1197. 
citizens of member states to the Inter-American Convention receive all of the rights granted under the Lanham Act, but also any additional rights granted by that convention. ${ }^{248}$ Writing just after the passage of the Lanham Act, Ladas admonishes, "[i]n considering the position of a foreign trade-mark owner claiming the benefits of ... the Inter-American Convention, we must always lean to such interpretation of the provisions of the Act which will give effect to the stipulations of the Convention, since the definite object of the Act is to give effect to the Conventions." 249

Section 44, however, was more than just a vehicle to effectuate the rights of member states to the Inter-American Convention. Significantly, it also extended the treaty protections against unfair competition to U.S. citizens. ${ }^{250}$ In so doing, the Lanham Act not only returned to the federal courts jurisdiction over unfair competition claims, but expanded the reach of those claims by means of an innovative treaty.

\section{The Drafting Choice Made by Rogers}

Why would Rogers, who spent the bulk of his professional life advocating for stronger protections against unfair competition, choose such a circuitous route to insert these rights into the Lanham Act? Ladas later commented on this legislative drafting choice, observing that Sections 44(h) and (i) "have the effect of placing trade-names and unfair competition under Federal control." ${ }^{251} \mathrm{He}$ conceded that "this could be done directly insofar as interstate commerce is concerned, and it may be done thus indirectly in a provision extending rights to foreigners and then securing the same benefits to American citizens and residents as to foreigners." 252

Ladas and Rogers provide differing accounts of how the peculiar Section 44 came into existence. According to Ladas, Rogers proposed the idea of including in the act a special title: "International Conventions" "[i]n late November, 1937," which Ladas then drafted. ${ }^{253}$ According to Rogers, however, he drafted this section

248 The Supreme Court in Bacardi made this point plainly: "Undoubtedly the Contracting States are bound respectively to give to the nationals of the other Contracting States the same rights and remedies that are extended to their own nationals. That is provided in Article 1. But that provision does not exhaust the rights given by the treaty." 311 U.S. 150, 165 (1940).

Ladas, supra note 2321 , at 280. See Lanham Act $§ 44(i), 15$ U.S.C. $§ 1126(i)$.

251 Ladas, supra note 232 , at 288.

252 Id.; see also Robert, supra note 238, at 180 ("Somewhat indirectly, but nevertheless effectively, a Federal Code of unfair competition is thus incorporated into our law.").

253 Ladas, supra note 232, at 278 ("[Rogers] telephoned me and suggested that it would be a good idea to include in the new Trade-Mark Act a separate chapter on International Conventions. ... I submitted draft of a chapter that contained Sections A to I. This is what is now Section 44 and my Sections A to I are the subsections of Section 44 . Aside 
with John Dienner, president of the American Group of the International Association for the Protection of Industrial Property and former delegate to the Paris Convention. ${ }^{254}$ Each must be referring to the specific language of the 1938 bill because the earliest formulation of an international convention provision dates back to the 1925 "Rogers Bill." That bill included a section titled "Paris Convention," which read:

Every owner of a trade-mark, being domiciled in any country which is a party to the [Paris] Convention ... shall enjoy with respect to the registration of said trade-mark and while such registration remains in force all the rights and benefits concerning trade-marks and unfair competition conferred by said convention, in so far as the same are not contrary to the provisions of this act. 255

As with Section 44, this provision appears to incorporate by reference all additional benefits of the treaty not otherwise provided in the act. ${ }^{256}$ Unfair competition in the Paris Convention would have been then on the drafters' minds since it had just been revised that year to provide broader unfair competition protections. ${ }^{257}$ The 1925 draft also included a section devoted to the predecessor PanAmerican convention, referred to in the bill as the "Bueno Aires Convention." 258 That section stated that treaty beneficiaries "shall enjoy .... all the rights and benefits conferred by articles 2 to 10 , inclusive, of said convention, in so far as the same are not contrary to the provisions of this act." 259 Thus the 1925 bill, like its successor, unmistakably aims to incorporate treaty rights not otherwise granted by the statute.

Still as Rogers undoubtedly intended to establish robust federal protections against unfair competition, he could have done so in a

from certain changes in literary style to make it conform to the rest of the Act, the present Section 44 is practically the text Mr. Rogers and I prepared in 1937.").

See Hearings on H.R. 4744, supra note 196, at 164; Hearings on H.R. 9041, supra note 58 , at 195 .

$255 \quad$ S. 2679, 68th Cong. § 6(b) (1st Sess. 1925).

256 Likewise, this earlier draft also provides for national treatment in addition to these treaty rights. The subsequent paragraph reads:

Foreign or alien owners of trade-marks used in this country shall otherwise enjoy the same right to such trade-marks at common law, and the same right to register or enforce such trade-marks under the other sections of this act, as in the case of citizens or residents of the United States, and their rights of priority shall be determined by their actual use of such trade-marks within the United States. Id.

See supra note 143.

See Joint Hearings Before the Comm. on Patents: A Bill to Protect Trade-Marks Used in Commerce, to Authorize the Registration of Such Trade-Marks, and for Other Purposes S. 2679, 68th Cong. (2d Sess. 1925).

Id. 
more direct manner. Rogers likely thought it unnecessary to codify unfair competition protection in the Lanham Act as they were already adequately specified in the Inter-American Convention, which was self-executing, as had recently been confirmed by the Supreme Court.

Again, evidencing his belief that the Inter-American Convention was self-executing, Rogers testified that "in the case of a foreigner, ... he would sue under the treaty, and that would be a Federal question anyhow." 260 Nevertheless, Rogers advocated for having language in the act that a treaty beneficiary could point to in order to sue in federal court for substantive rights provided in the InterAmerican Convention. Rogers remonstrated, "I do not want the finger of scorn pointed at us, because they say, 'Here, you have guaranteed to do certain things ... but you have got to do it by statute. Now how do you expect us to protect your citizens down here when you don't do it up there?' Now that is the point and it is a pretty hard question to answer." 261 One answer is, of course, that the convention is self-executing in the United States. It seems clear, however, that Rogers was either using this rhetorical question as a tactical measure to get his bill passed, or he was seeking to achieve a strategic advantage diplomatically.

More fundamentally, however, although Rogers would have been perfectly happy to enact directly the newly invented, sweeping unfair competition protections included in the Inter-American Convention, his sophisticated understanding of the limits and possibilities of unfair competition law based on decades of advocacy, research, and drafting would have suggested to him that Congress was not ready to enact the full ambit of protections. The congressional hearings and redrafting efforts took place during a period that was rather inhospitable to broad protections.

The history of unfair competition law in the United States from the late $1800 \mathrm{~s}$ to the present consists of various periods of acceptance and rejection of its reach. Given its beginnings at the turn of the 19th century and its growth through the 1920s, unfair competition law's development tracks significant changes in legal thought from formalism to Legal Realism and its aftermath. ${ }^{262}$ Unfair competition had its birth in the era of classical legal thought where rules prevailed and were derived from principles in common

\footnotetext{
260 Hearings on H.R. 4744, supra note 196, at 169.

261 Id.

262 Legal realism reached its pinnacle in the 1930s. See American Legal Realism (William W. Fisher, Morton J. Horwitz, \& Thomas A. Reed, eds. 1993); Grant Gilmore, The Ages of American Law 68-111 (1977); G. Edward White, From Sociological Jurisprudence to Realism: Jurisprudence and Social Change in Early Twentieth-Century America, 58 Va. L. Rev. 999, 1017 (1972).
} 
law. 263 Just when unfair competition law had its greatest opportunity to expand, following International News, ${ }^{264}$ however, it came within the crosshairs of Legal Realism. In fact, Justice Brandeis's dissent in that case portended trouble for unfair competition proponents. 265 Thereafter, the expansion of common law in this area was subject to the realist critique. ${ }^{266}$

Rogers was pushing his drafts in the era of Legal Realist critique and the fallout of Erie. ${ }^{267}$ As there was no federal common law to codify, there was increased skepticism to the creation of new unfair competition rights. ${ }^{268}$ In addition, beginning in 1938, the Department of Justice effectively mounted opposition to the act's creation of new and stronger rights by arguing that it was anticompetitive and endangered monopolies. ${ }^{269}$

Therefore, the 1930s-precisely the period when Rogers's bill was being debated-was a particularly difficult time to be arguing for new and expanded rights. If the United States already agreed to these new unfair competition protections in a self-executing treaty, however, they were not new. Still, it may have been perceived as a risky strategy to trumpet these treaty rights and argue that Congress was stuck with them. Opponents may have attempted to defeat these treaty protections in the new trademark act under the "last-in-time" rule, which provides that federal statutes may rescind

263 See American Legal Realism, supra note 262, at xii ("When no prior decision seemed directly applicable, a court often would attempt to extract from the rulings made in a group of loosely related prior cases a general principle (the more abstract and encompassing the better) that could be brought to bear on the case before it.").

264 Nims, supra note 4, at viii ("[Unfair competition law] is still in its infancy.").

265 Int'l News Serv., 248 U.S. at 258 (Brandeis, J., dissenting) ("Such taking and gainful use of a product of another which, for reasons of public policy, the law has refused to endow with the attributes of property, does not become unlawful because the product happens to have been taken from a rival and is used in competition with him.”).

266 Among the direct attacks was a law review written by Felix Cohen who revealed the circularity of thinking about goodwill as property when it only has the attributes of property that the law has bestowed upon it. Felix Cohen, Transcendental Nonsense and the Functional Approach, 35 Colum. L. Rev. 809 (1935). Others who contributed to the realist attack on trademark and unfair competition law include Milton Handler \& Charles Pickett, Trade-Marks and Trade Names-An Analysis and Synthesis (pt. 1), 30 Colum. L. Rev. 168 (1930); Edward Chamberlin, The Theory of Monopolistic Competition (1933); Chafee, supra note 21; Ralph S. Brown, Jr., Advertising and the Public Interest: Legal Protection of Trade Symbols, 57 Yale L.J. 1165 (1948)). See, e.g., Cohen, supra note 266, at 815.

268 Notably, the first hearings on that bill just preceded the Supreme Court's decision in Erie on April 25, 1938. Hearings on H.R. 9041, introduced by Fritz Lanham on January 19, 1938 (75th Cong., 3d Sess.), before the Subcommittee of the House Committee on Patents were held on March 15-18, 1938. Erie Railroad Co. v. Tompkins was decided on April 25, 1938.

269 See McCarthy, supra note 2 , at $\S 5: 4$. 
any earlier conflicting treaty provisions. ${ }^{270}$ Given this possibility, it would have been prudent to not call any undue attention to the precise scope of these treaty rights.

\section{THE REVIVAL OF UNFAIR COMPETITION UNDER SECTION 43(A)}

After the passage of the Lanham Act in 1946, it must have seemed that trademark owners had a dazzling set of comprehensive protections at their disposal. They had a wider net to catch those who infringed their registered marks, ${ }^{271}$ a means to register marks that had previously been denied registration, ${ }^{272}$ and an avenue to federal court to enjoin those who infringed their unregistered marks. ${ }^{273}$ Trademark owners also now had an arsenal of additional protections that went well beyond trademark rights even broadly imagined via Section 44 and the Inter-American Convention. These protections addressed not only the unfair acts that were then known, but also offered an avenue to protect against as of yet unforeseen unfair acts.

The Ninth Circuit was the first federal court of appeals to hold that Section 44 gives jurisdiction to the district court over claims of unfair competition. In 1950, in Stauffer v. Exley, ${ }^{274}$ the court ruled in favor of the owner of a trade name used in interstate commerce on a claim of unfair competition. It held that it had jurisdiction under Section 44(h) to hear the case despite the absence of diversity of citizenship even though the case involved a bald claim of unfair competition unadorned by any other federal claim. Nevertheless, the court held that the defendant's use in commerce of names that referred to the plaintiff's exercise systems, but that were not registered by the plaintiff, was actionable as unfair competition under Section 44(h) and (i). The court's approach to Section 44 was adopted in a subsequent decision in Ninth Circuit ${ }^{275}$ and followed in a decision by the Court of Customs and Patent Appeals in 1951.276

270 See, e.g., Whitney v. Robertson, 124 U.S. 190, 194 (1888) (holding that if a treaty and a federal statute conflict, "the one last in date will control the other"); The Cherokee Tobacco, 78 U.S. 616, 621 (1870).

271 Lanham Act $§ 32(1), 15$ U.S.C. $\$ 1114(1)$.

272 Lanham Act $\S 1(a)(1), 15$ U.S.C. $§ 1051(a)(1)$.

273 Lanham Act $\S 43(\mathrm{a}), 15$ U.S.C. $§ 1125(\mathrm{a})$.

274184 F.2d 962, 966 (9th Cir. 1950) (Section 44 creates a cause of action for unfair competition upon which federal courts have jurisdiction.).

275 See Pagliero v. Wallace China Co., 198 F.2d 339 (9th Cir. 1952) (Section 44 gives jurisdiction to the court over claims of unfair competition). See also Neal v. Thomas Organ Co., 325 F.2d 978 (9th Cir. 1963); Magna Pictures Corp. v. Paramount Pictures Corp., 265 F. Supp. 144, 153 (C.D. Cal. 1967); Volkswagenwerk Aktiengesellschaft v. Church, 256 F. Supp. 626 (S.D. Cal. 1966).

276 The Court of Customs and Patent Appeals (C.C.P.A.) approved this doctrine obiter. In re Lyndale Farm, 186 F.2d 723, 738 (C.C.P.A. 1951) ("Section 44(i) of the Act, 15 U.S.C.A. 
These cases, however, are not representative of court's receptivity to federal unfair competition claims. The decisions in the decades following enactment of the Lanham Act were confused but evidenced an overall wariness of claims of unfair competition brought under the act. Some courts roundly rejected the idea that the Lanham Act enacted any unfair protection at all. ${ }^{277}$ These courts endeavored to construe the statute so as to preserve common law limitations on unfair competition such as the requirements for a passing off claim. ${ }^{278}$

Other courts were specifically hostile to the suggestion that Section 44 provided a federal cause of action for unfair competition. ${ }^{279}$ These courts were dubious that Congress intended such a sweeping change through so circuitous a route. One district court explained its hesitancy to follow the Ninth Circuit's approach:

It is doubtful whether the guarantee in the treaties of the repression of unfair competition was intended to be broader than the protection of trade-marks or trade names, or at least that that was the understanding of Congress when the Lanham Act was enacted. However that may be, I do not think that Subsection (i) which gives to citizens of the United States "the same benefits as are granted by this section" to foreign nationals could have been intended to effect the revolutionary expansion of federal jurisdiction for which the plaintiff contends. ${ }^{280}$

$\S 1126(\mathrm{i})$, read in connection with Section 44(g), 15 U.S.C.A. $§ 1126(\mathrm{~g})$ and Section 44(b), 15 U.S.C.A. $\$ 1126(\mathrm{~b})$ confers upon trade names increased protection from acts of unfair competition.").

277 Royal Lace Paper Works, Inc. v. Pest-Guard Prods., Inc., 240 F.2d 814, 818 (5th Cir. 1957) ("Specifically concerned, as it is, with registered trade marks, it would, we think, be to rewrite instead of to construe the statute if we should read it as including within its scope unregistered trade marks or unfair competition generally."); City Messenger of Hollywood v. City Bonded Messenger Serv., 254 F.2d 531, 533-34 (7th Cir. 1958) ("This Court is committed to the view that the claim set forth in Count I of the counterclaim for damages caused by unfair competition is governed by the law of Illinois. We do not think that the Lanham Act changed this rule.") (citations omitted); Kaz Mfg. Co. v. Chesebrough-Pond's, Inc., 211 F. Supp. 815, 824 n.23 (S.D.N.Y. 1962) ("this Circuit rejects that notion that the Lanham Act itself creates a cause of action for unfair competition").

278 See, e.g., Chamberlain v. Columbia Pictures Corp., 186 F.2d 923 (9th Cir., 1951); Samson Crane Co. v. Union Nat'l Sales, Inc., 89 F. Supp. 218 (D.C. Mass. 1949).

279 Ross Prods., Inc. v. Newman, 94 F. Supp. 566, 567 (S.D.N.Y. 1950) ("If Congress had intended to work so radical a change in the law, it undoubtedly would have embodied that purpose in clear and unmistakable language."); Ronson Art Metal Works, Inc. v. Gibson Lighter Mfg. Co., 108 F. Supp. 755, 756-57 (S.D.N.Y. 1952) ("The problem is as delicate and complex as it is important, with both views having much to recommend them. However, in the absence of a ruling by the Court of Appeals for this Circuit, and without attempting to make any novel contribution toward the resolution of the problem, I am constrained to adopt the view of Judge Ryan in the Ross Products case.").

L’Aiglon Apparel v. Lana Lobell, Inc., 118 F. Supp. 251, 253-54 (E.D. Pa. 1953). 
As other circuits considered Section 44, two lines of authority emerged. In contrast with the Ninth Circuit, the Second Circuit read Section 44 more narrowly and saw it as primarily a means of implementing treaty law, not enacting sweeping changes to unfair competition law. Specifically, the Second Circuit, in an opinion by Judge Learned Hand, reasoned that Section 44 merely grants U.S. citizens reciprocal rights against foreign nationals where foreign nationals would have a right under the treaty. ${ }^{281}$ That is, Section 44 relieved only a subset of U.S. claimants from the diversity and pendent jurisdiction prerequisites and did not create a federal law of unfair competition available to U.S. citizens generally.

According to the Second Circuit's interpretation of Section 44, subsection (i) only grants U.S. citizens the protection that foreigners get under subsection (h), which is limited in its coverage by subsection (b). The difference between the Ninth and Second Circuit's interpretations centers on whether subsection (b) is to be read as simply identifying the foreigners who are entitled to the section's benefits, or as limiting its application. That is, subsection (b) either invokes the additional substantive rights of the treaties or limits the courts' jurisdiction to cases necessary to carry out our treaty obligations.

Given the heady issues raised by this circuit split, it is no wonder that district courts in other circuits sought an alternate means of resolving these claims. The Third Circuit provided such an alternative. The Third Circuit sided with the Second Circuit on the reach of Section 44. Noting that Section 44 is located in the "International Conventions" section of the act, it queried whether Congress intended, by inserting "language in a title implementing international conventions, to establish a federal law of unfair competition in commerce unrelated to any matter arising out of some international convention or treaty?" 282 Relying on the legislative history and giving great weight to Byerly's interjections and the location of Section 44 in the section dealing with treaties, it concluded that Congress sought only to implement non-selfexecuting treaties and not to grant the federal courts any new authority to hear unfair competitions claims broadly construed. ${ }^{283}$

Although the court rejected the plaintiff's Section 44 claim, it nevertheless allowed it to assert a non-trademark claim under the act without diversity jurisdiction. The court held that Section 39 dispenses with the necessity to show diversity of citizenship or any jurisdictional amount in cases falling under the act, and that Section 43(a) provides a cause of action for a use of a false

281 AAA v. Spiegel, 205 F.2d 771, 775 (2d Cir. 1953). Accord Old Reading Brewery, Inc. v. Lebanon Valley Brewing Co., 102 F. Supp. 434, 438-339 (M.D. Pa. 1952).

282 L'Aiglon Apparel v. Lana Lobell, Inc., 214 F.2d 649, 652 (3d Cir. 1954).

283 Id. at $653-54$. 
representation in the description of goods sold in commerce. ${ }^{284}$ The court concluded that the text of Section 43(a) unambiguously evidenced Congress's intent to change the common law with regard to the requirements of false representation claims.

The path opened up by the Third Circuit enabled federal question jurisdiction over any unfair competition claim addressed in Section 43(a). This proved more palatable as a less dramatic expansion of federal unfair competition law. It also provided a more routine approach to legislative change, which courts favored over the tenuous suggestion in Section 44. The elegant simplicity of Rogers's approach was just too understated. As Professor Derenberg observed a decade after the Lanham Act's enactment, "this method for the establishment of a national unfair competition law, derived from certain provisions of various international conventions, was quite obviously too subtle and indirect in approach to meet with the approval of our courts." 285 Section 44 quickly came to be disfavored by U.S. courts and was even abandoned by the Ninth Circuit. ${ }^{286}$

Rogers himself had no opportunity to influence the interpretation of Section 44. When the act became effective in 1947, he was consumed with serving as the Chairman of the Board for the Sterling Drug Company, and he died in 1949 before any case was litigated relying on Section $44 .^{287}$

Thus in the years following passage of the Lanham Act, unfair competition lay dormant. When it finally did emerge, it sprang not from Section 44, but instead from the "minor," "unnoticed" Section 43(a). ${ }^{288}$ That eventuality, however, took decades to

$284 \quad I d$. at 651.

285 Walter J. Derenberg, Federal Unfair Competition Law at the End of the First Decade of the Lanham Act: Prologue or Epilogue?, 32 N.Y.U. L. Rev. 1029, 1031 (1957).

286 See, e.g., Toho Co., Ltd. v. Sears, Roebuck \& Co., 645 F.2d 788, 792 (9th Cir. 1981). According to McCarthy, the Toho decision "caused hardly a ripple in the world of intellectual property law, because by then all eyes were focused on section 43(a)." J. Thomas McCarthy, Lanham Act § 43(a): The Sleeping Giant is Now Wide Awake, 59 Law \& Contemp. Probs. 45, 50 (1996).

287 Rogers died in 1949. See Obituary, E.S. Rogers, Expert on Patent Law: Board of Chairman of Sterling Drug Co. Dies-Sponsored Many Fair-Trade Statutes, 74, N.Y. Times, May 23, 1949. Rogers had a posthumously published article co-authored with Ladas in which they proposed a new Inter-American Trademark Convention to deal with the problem of foreign preemptive registration and to address the limited membership of the 1929 convention. See Rogers and Ladas, supra note 150, at 13-14 ("the only practical and effective method of adopting uniform solutions of these problems or of establishing harmony between the legislation of the various countries on these questions is the adoption of an Inter-American Trade-Mark Convention with suitable stipulations").

288 McCarthy, supra note 2, at $§ 27: 7$; Derenberg, supra note 285, at 1031 . In his treatise, McCarthy notes Derenberg's prescience about Sections 44 and 43(a) in this article: "As early as 1957 Professor Derenberg could state with remarkable foresight that $\S 44$ was epilogue and $\S 43($ a) was the prologue of a federal law of unfair competition.” McCarthy, supra note 2 , at $\S 27: 7$. 
transpire ${ }^{289}$ as the courts were initially skeptical of these claims as well 290 and subjected them to the narrowness that Byerly intended. ${ }^{291}$ But just as had occurred in the early 1900s, a period of enlargement soon followed. The pressure that built up eventually forced a broader reading of Section 43(a). ${ }^{292}$ Unfair competition law's pattern of erratic development thus continued into the modern era.

At the time of enactment in 1946, Section 43(a) was intended to be limited to false indications of geographic origin and false descriptions or representations. It was not intended to broadly address unfair competition. ${ }^{293}$ In its original text, the cause of action under Section 43(a) for use in commerce of "a false designation of origin, or any false description or representation, including words or other symbols tending falsely to describe or represent the same" was limited to "any person doing business in the locality falsely indicated as that of origin or in the region in which said locality is situated, or by any person who believes that he is or is likely to be damaged by the use of any such false description or representation." 294 That language makes clear that our modern understanding of "origin" does not comport with the drafters' intent. Whereas today we understand origin to mean source of origin, the original language of

289 Not until Section 43(a) "was about twenty-five years old [did] its potentialities [begin] to be realized." McCarthy, supra note 2, at § 27:7.

290 See, e.g., Chamberlain v. Columbia Pictures Corp., 186 F.2d 923 (9th Cir. 1951); Samson Crane Co. v. Union Nat'l Sales, Inc., 87 F. Supp. 218 (D. Mass. 1949), aff'd, 180 F.2d 896 (1st Cir. 1950); Bechik Prods., Inc. v. Fed. Silk Mills, Inc., 135 F. Supp. 570 (D. Md. 1955).

291 Iowa Farmers Union v. Farmers' Educ. \& Coop. Union of Am., 247 F.2d 809, 819 (8th Cir. 1957) ("We do not consider that this case raises the question and we do not hold that the Lanham Act would confer federal jurisdiction for unfair competition when there is no substantial related claim of infringement under the Act."); Samson Crane Co. v. Union Nat'l Sales, Inc., 87 F. Supp. 218, 222 (D. Mass. 1949) ("that phrase ('to protect persons engaged in such commerce against unfair competition') must in such a context be construed to refer not to any competitive practice which in the broad meaning of the words might be called unfair, but to that 'unfair competition' which has been closely associated with the misuse of trade-marks, i.e., the passing off of one's own goods as those of a competitor.”); Gen. Pool Corp. v. Hallmark Pool Corp., 259 F. Supp. 383, 385 (N.D. Ill. 1966) ("Section 43(a) must be read to embrace only those kinds of unfair competition which are analogous to, or associated with, the misuse of trademarks or tradenames, and which produce the same kinds of injuries.").

292 For instance, a concurring opinion in a Second Circuit case in a 1956 case in which the plaintiff did not make a claim under Section 43(a), observed that "[T] here and elsewhere that the bar has not yet realized the potential impact of this statutory provision.” Maternally Yours, Inc. v. Your Maternity Shop, Inc., 234 F.2d 538, 546 (2d Cir. 1956) (concurring opinion).

293 This understanding was reconfirmed in the legislative history of the 1988 revision. Trademark Law Revision Act of 1988, Pub. L. 100-667, 102 Stat. 3935 (effective Nov. 16, 1989).

294 Lanham Act $\S 43(a), 15$ U.S.C. $§ 1125(a)$. 
the act meant origin only in its geographic sense. ${ }^{295}$ As a result, Section 43(a) did not originally provide a general cause of action for unregistered marks.

Congress made significant substantive revisions to the Lanham Act in 1988. ${ }^{296}$ Along with other amendments, Congress broadened Section 43(a). ${ }^{297}$ Congress was explicit that the amendments created rights in unregistered marks and created a false advertising right. ${ }^{298}$ The amendments were also intended to codify the courts' expansive interpretations of Section 43(a). ${ }^{299}$ As Senator DeConcini emphasized, the amendment amended "the language of section 43(a) of the Lanham Act to conform it to the expanded scope of protection it has been given by the courts." 300 The Supreme Court stated that Congress gave "its imprimatur to a growing body of case law from the Circuits that had expanded the section beyond its original language." 301 Congress also codified case law on false advertising and created a second statutory prong-subsection 43(a)(1)(B). ${ }^{302}$

After 1988, Section 43(a) continued to expand beyond the amendments. An example of this expansion is the decision in Two Pesos, Inc. v. Taco Cabana, in which the Supreme Court held that unregistered trade dress may be protected absent secondary meaning in a case involving a claim that the general appearance of a restaurant was instantly protectable as a nonfunctional, inherently distinctive mark. ${ }^{303}$ The Court thus blurred any distinctions between trademarks and trade dress, as well as

McCarthy, supra note 2, at § 27:7 (“The phrase 'false designation of origin' was thought to be limited to false advertising of geographic origin."). A broadened sense of origin was enabled by a 1963 Sixth Circuit opinion. See Federal-Mogul-Bower Bearings, Inc. v. Azoff, 313 F.2d 405 (6th Cir. 1963) (finding "origin" to include "origin or source of manufacture").

296 The main thrust of these amendments was to create an intent-to-use system for registration and to include anti-dilution protections. The anti-dilution provisions were not enacted until 1995. McCarthy, supra note 2 , at $\S 5: 9$.

297 See McCarthy, supra note 286, at 53 (providing a comprehensive overview of the codification of the 1989 rewriting of Section 43(a) into subsections (1)(A) and (1)(B) to replace "the by then archaic 1946 language with wording that reflected the reality of case law interpreted"). Handler notes that the revisions eliminate the "original ambiguities" of Section 43(a). Handler, supra note 304, at 8.

McCarthy, supra note 286, at 53-54 ("The 1989 revision divided section 43(a) into two distinct sub-sections: the first part relating to use of the statute as a vehicle for assertion in federal court of unregistered trademark ... the second part relating to use of the statute as a vehicle for assertion in a federal court of false advertising (as well as product disparagement claims.").

299 See id. at 53 ("section 43(a) was substantially rewritten, in large part to codify the case law interpretation of previous version of section 43(a)").

300134 Cong. Rec. 5864, 5869 (1988) (Statement by Sen. DeConcini) (emphasis added).

301 See Two Pesos, Inc. v. Taco Cabana, 505 U.S. 763, 783 (1992).

302 See McCarthy, supra note 2, at § 27:10.

303505 U.S. 763 (1992). 
trademark infringement and unfair competition. The result was an expanded protection for unregistered trade dress where the impression of the appearance of a product could be substituted for the evidentiary association that had formed the foundation for the protection of goodwill.

The extent to which trademark rights eventually would grow and the manner in which unfair competition protection would be provided could not easily have been surmised from the act's 1946 text. The most elastic provision was Section 43(a). Professor Handler, reflecting on the impact of the Lanham Act fifty years after its passage, declared that "Section 43(a) has been the fountainhead of a vast body of law, which now constitutes a federal common law of trademarks and unfair competition." 304

The reach of Section 43(a)'s unfair competition protection is, however, short of Rogers's aspirations for Section 44(h). As the Supreme Court acknowledged, Section 43(a) "does not have boundless application as a remedy for unfair trade practices." 305 The Court noted that " [b] ecause of its inherently limited wording, $\S$ 43(a) can never be a federal 'codification' of the overall law of "unfair competition." 306 Because of late utilization of Section 43(a), beginning in the 1970s and then following the 1988 amendment, unfair competition developed in a particular way. It was focused on claims of false source identification and false advertising. It is worth considering whether unfair competition would have developed differently if Section 44(h) had operated as intended.

Despite Rogers's successes in the early 20th century shaping unfair competition law in both treaty and statute, his vision has not come to be. Rogers's conception of unfair competition is absent from modern cases, as most courts rejected his approach.

\section{THE UNBEATEN PATH}

This article has explained why unfair completion remains uncertain today after over a century of litigation. The sweeping protections for unfair competition law never materialized and we are left with sporadic innovations under Section 43(a). The state of unfair competition law today, however, still falls short of Rogers's vision. While a full analysis of the present-day viability of the path to unfair competition claims envisioned by Rogers is beyond the scope of this article, some suggestion about what unfair competition

304 Milton Handler, A Personal Note on Trademark and Unfair Competition Law Before the Lanham Act, 59 L. \& Contemp. Probs. 5, 9 (1996) ("Section 43(a), in my opinion, is the most significant advance wrought by the Lanham Act ... ").

305 Dastar Corp. v. Twentieth Century Fox Film Corp., 539 U.S. 23, 29 (2003) (quoting Alfred Dunhill, Ltd. v. Interstate Cigar Co., 499 F.2d 232, 237 (1974).

306 Id. (quoting 4 J. McCarthy Trademarks and Unfair Competition § 27:7, pp. 27-14 (4th ed. 2002)). 
law could look like in light of this history is in order. This section will briefly sketch the normative basis for reclaiming the unfair competition law that was lost along the way.

In addition to the junctures where we went off the course set by Rogers described in this article, some new obstacles have arisen that threaten to block that path. For a plaintiff to successfully state a claim for unfair competition under Section 44(h) or the InterAmerican Convention today, these historic and more recent wrong turns would need to be corrected.

The historical background of Section 44 here recounted should make clear that as the main drafter of the Lanham Act, Rogers did mean to enact a federal law of unfair competition as well as implement our treaty obligations. The decisions in the 1950s that the language of Section 44 intended only the latter are incorrect. Rogers drafted subsection (i) with the intent to give U.S. parties federal question jurisdiction. Believing the Inter-American Convention to be self-executing in this country and all other member states, Rogers was concerned that foreign parties had rights in the United States, and that U.S. parties had rights in member states, but that U.S. parties did not have rights in the United States. Subsection (i) was intended to correct that "anomalous" situation. ${ }^{307}$ It would have been perverse to grant U.S. parties only a fraction of the rights granted to foreign parties so that foreign parties could sue U.S. parties, but U.S. parties could not. 308

Whether Rogers's drafting intentions mirrored Congress's intentions is difficult to determine. It is possible that Rogers was being crafty in hiding a federal code of unfair competition within provisions that may have seemed only to implement international obligations. ${ }^{309}$ Rogers may have been a few steps ahead of Congress, but this article has pointed to numerous places in the act's text and

307 Rogers, supra note 32, at 132 ("[e]ffective protection against these acts is assured to foreigners. This is a nation-wide right accorded to foreigners under the treaty making power which, under the Constitution, is given to the National government. These treaties guarantee the same protection to American nationals in foreign countries. It is said that these rights are not conferred upon American citizens in the United States; but they are I submit, rights which they ought to have and I believe they do have. American nationals ought not, I should suppose, have less rights at home than they have abroad, or at home, less than foreigners.").

308 Daphne Robert, Commentary on the Lanham Trade-Mark Act, 86 TMR 373, 393 (1996) ("Congress recognized the need for uniform protection-particularly since foreign nationals were entitled to uniform protection under the international conventions. The new Act gives to citizens and residents of the United States the same protection against unfair competition as has been afforded foreign nationals under the conventions, and the acts which are made unlawful are those set out in the conventions.").

309 David B. Wolf, "Effective Protection Against Unfair Competition" Under Section 44 of the Lanham Act, 82 TMR 33, 35-37 (1992) ("The problem was that the proponents of Section 44 were using the unobjectionable goal of implementing [international] conventions to try to achieve the more controversial goal of overcoming the effects of Erie."). 
in the legislative history that evidence Congress's intent to provide U.S. parties the unfair competition protections enunciated in the Inter-American Convention through the Lanham Act. All of the comments by experts at the time of enactment reflect this understanding. ${ }^{310}$

Without relying on its precedent from the 1950s, the Second Circuit more recently revisited Section 44 in two cases involving well-known Cuban trademarks. These cases erected an additional hurdle. In Havana Club Holding, S.A. v. Galleon S.A., the court dismissed a claim for unfair competition brought under Section 44(h) and Article 21(c) of the Inter-American Convention concluding that the reach of Article 21 is limited by its text to covered acts not "effectively dealt with under the domestic laws of the Contracting States." ${ }^{111}$ The court found that the conduct covered by Article 21(c) was already effectively prohibited under Section 43(a). ${ }^{312}$ In Empresa Cubana Del Tabaco v. Culbro Corporation, a subsequent case involving a similar claim, the court held that claims under Articles 20 and 21 were likewise already addressed by the language of Section 43(a) and therefore impermissible under Section $44 .{ }^{313}$ As has already been shown above, in addressing the whole of unfair competition law, these articles go beyond Section 43(a)'s limited reach. ${ }^{314}$ Since Article 20 broadly states that "[e]very act or deed contrary to commercial good faith or to the normal and honorable development of industrial or business activities shall be considered as unfair competition and, therefore, unjust and prohibited," and Article 21(e) includes the catcall that "[a]ny other act or deed contrary to good faith in industrial, commercial or agricultural matters which, because of its nature or purpose may be considered analogous or similar to those above mentioned," it is difficult to see how the Second Circuit could find these provisions synonymous with Section 43(a). ${ }^{315}$

A close analysis reveals other distinctions between Section 43(a) and Articles 20 and 21. Significantly, protection under the convention does not require the showing of a belief in likely damage

310 See, e.g., Robert, supra note 308, at 394 (stating that the acts prohibited as unfair competition under the Inter-American Convention and Paris Convention "constitute[ the federal code of unfair competition under the new statute and the Federal Courts have jurisdiction of all actions to enjoin any of such acts, irrespective of the amount in controversy or diversity of citizenship of the parties. Suits involving any of the acts of unfair competition set out above are suits arising under federal law."); Robert, supra note 238, at 177, 180; Derenberg, supra note 285, at 1031; Callmann, supra note 228, at 1057-58; Ladas, supra note 232, at 288-89; Diggins, supra note 169, at 207-08; March, supra note 243 , at 737 .

311203 F.3d 116, 134 (2d Cir.) (quoting the convention, Art. 21, 46 Stat. at 2932).

312 Id.

$313 \quad 399$ F.3d 462 (2d Cir. 2005).

314 See supra note 138 and accompanying text.

315 Inter-American Convention, supra note 8. 
as is required under Section 43(a). ${ }^{316}$ Moreover, a successful action may lie under the convention where the plaintiff cannot prove a likelihood of confusion, but nevertheless has evidence of a calculated misrepresentation. At a minimum, in these ways, acts proscribed by the convention are not "effectively dealt with" in Section 43(a) and should be actionable under Section 44(h).

The Fourth Circuit's Belmora decision does not pose any obstacle to following the path set by Rogers, but may serve to take us off course. In dispensing with use of a mark in the United States as a "condition precedent" to a Section 43(a) claim, Belmora is a watershed in the development of unfair competition law. ${ }^{317}$ Like previous expansions under Section 43(a), this development will likely distract from the potential of Section $44 .{ }^{318}$

Belmora's decoupling of unfair competition law from trademark law could enlarge the reach of unfair competition law exponentially without resort to Section $44 .{ }^{319}$ Not only did the plaintiff not have a trademark, but in addition, the parties were not in competition as the plaintiff was not selling its branded product in the United States. ${ }^{320}$ Nevertheless, the court held that this was actionable unfair competition under Section 43(a). The Belmora decision highlights an irony in the development of unfair competition law: Section 43(a) became the vehicle for unfair competition claims only due to fears about the unlimited scope of Section 44, but now Belmora has removed the last vestiges of traditional trademark limitations on unfair competition claims.

316 Id. (“Any person who shall . . . cause such goods or services to enter into commerce . ..”); see also Stauffer, 184 F.2d at 966.

317819 F.3d 697.

318 Belmora has already been followed by the Court of Appeals for the District of Columbia Circuit. Paleteria La Michoacana, Inc. v. Productos Lacteos Tocumbo S.A. de C.V., 743 Fed. Appx. 457 (D.C. Cir. 2018).

319 The enlargement of claims beyond trademark claims under Section 43(a) may take on even greater significance depending on the resolution of an issue prompted by recent litigation. The Court of Appeals for the Federal Circuit has suggested that mark owners that are refused registration may not bring actions for unregistered marks under Section 43(a). See In re Tam, 808 F.3d 1321, 1344 n.11 (Fed. Cir. 2015) (en banc), aff'd on other grounds, Matal v. Tam, 582 U.S. __, 137 S. Ct. 1744 (2017). Although only dictum, at least one district court has reached exactly this result. See Renna v. Cty. of Union, 88 F. Supp. 3d 310, 321 (D.N.J. 2014). The Supreme Court did not resolve this issue in either Tam or Brunetti. Tam, 582 U.S. 137 S. Ct. at 1752 n.1; Iancu v. Brunetti, 588 U.S. _ 139 S. Ct. 2294 (2019). Indeed, the Court may have itself prompted this issue with its dictum in Taco Cabana: "[Section 43(a)] protects qualifying unregistered trademarks and ... the general principles qualifying a mark for registration under $\S 2$ of the Lanham Act are, for the most part, applicable in determining whether an unregistered mark is entitled to protection under $\S 43(\mathrm{a})$." Taco Cabana, Inc., 505 U.S. at 768 (citation omitted). Either way this issue is resolved, the reliance on Section 43(a) will increase. It may remain a vehicle for unregistered marks, or following Belmora, it may be a means to circumvent a defective trademark altogether. 
After Belmora, the most significant hurdle for non-trademark owner claiming unfair competition in the United States is standing. The Supreme Court announced a standing test applicable to Section 43(a) in Lexmark International Inc. v. Static Control Components, Inc.: plaintiffs must prove "interests [that] fall within the zone of interests protected" by the statute, and "injuries [that] are proximately caused by violations of the statute." ${ }^{221}$ The zone of interest requirement is satisfied when "it can be reasonably assumed that Congress authorized that plaintiff to sue." ${ }^{22}$ The Lanham Act's purpose statement in Section 45 helpfully identifies the statute's zone of interests for purposes of standing.

Whereas the Supreme Court pointed to Congress's stated intent "to protect persons engaged in ... commerce against unfair competition" in Lexmark, ${ }^{323}$ in Belmora the Fourth Circuit pointed to Congress's intent in "making actionable the deceptive and misleading use of marks in ... commerce." ${ }^{24}$ Presumably the Fourth Circuit picked an alternate intention identified because the Belmora plaintiff was not engaged in commerce. What has thus far escaped notice, however, is that the intention relied on requires the misleading use of a "mark," something the Belmora case did not involve. Defined by the act, a mark is a distinctive device used in commerce. ${ }^{325}$ This case involved the misleading use of a Mexican mark-a device that presumably meets the demands of Mexican trademark law. As the designation was not used in commerce, however, it cannot be a mark under U.S. law and therefore the Congressional intention identified by the court is not applicable.

The fact pattern in Belmora is precisely the case that was anticipated by Rogers and the scenario he sought to address in the Inter-American Convention. ${ }^{326}$ Rogers would have instead brought the case under Section 44(h) as one involving unfair competition and would have pointed to Congress's intention "to provide rights and remedies stipulated by treaties and conventions respecting trademarks, trade names, and unfair competition." 327 Since Bayer would have qualified as a treaty beneficiary under Section 44(b), it would have stated a cognizable claim under Section 44(h).

There is also a public policy benefit in resurrecting the Section 44 path in connection with a Belmora-style claim. After the

$321 \quad 572$ U.S. 118, 129-31 (2014).

${ }_{322} I d$. Proximate causality requires that the plaintiff's economic or reputational injuries be tied to defendant's conduct. Id. at 133 .

$323 \quad I d$. at 132.

$324 \quad 819$ F.3d at 711.

$325 \quad 15$ U.S.C. $\S 1127$.

326 See, e.g., Rogers, supra note 97, at 112 (complaining that the U.S. owner of the BIG BEN mark was powerless to stop a Mexican party who had been the first to adopt it there).

$327 \quad 15$ U.S.C. $\S 1127$. 
Belmora claimant demonstrated standing, there were no guardrails on the claim of unfair competition. Once the claim was unhinged from the precondition of a mark, there was no limitation on the protection. An unfair competition claim brought under Section 44 rather than Section 43(a) would offer the constraints contained in the Inter-American Convention.

Even before Belmora was decided, a path parallel to Section 44 was being paved. This course relies on the convention directly as a self-executing treaty. Such claims have proven successful in actions before the Trademark Trial and Appeal Board, which has held that the convention "is self-executing and independent of the Lanham Act." ${ }^{28}$ Outside of the Trademark Trial and Appeal Board, Bacardi has rarely been invoked on the self-execution point with respect to the Inter-American Convention, but two recent district court cases may signal a revival. A U.S. District Court for the Central District of California held that Article 18 of the convention contemplates a private right of action, ${ }^{329}$ and a U.S. District Court for the District of New Jersey held that Articles 1, 7, 8, 12, 17, 18, 30, and 31 of the convention create a private cause of action. ${ }^{330}$ While claims asserted directly under the convention avoid any misinterpretation of Section 44, they do require claimants to be treaty beneficiaries.

In sum, although some obstacles have sprouted up in the path set by Rogers, that path is not completely obstructed. Now that this article has indicated where once stood a shortcut to broad unfair competition claims, the courts will have to decide whether that path should now be cleared.

\section{CONCLUSION}

This article recounts a story in the development of unfair competition law, some of which has been forgotten and some of which had not yet been uncovered. Beyond the plot twists and interesting characters, this story helps explain why unfair competition law-an area of law that has been a part of U.S. law for over 100 years-is still so uncertain. It explains why the Fourth Circuit recently should have asked such a basic question: Does the Lanham Act permit a party that does not have a trademark to sue

328 British-American Tobacco, Co. Ltd., v. Philip Morris, Inc., 55 U.S.P.Q.2d (BNA) 1585, 1590, 2000 WL 1005433 (T.T.A.B. 2000); Diaz v. Servicios De Franquicia Pardo's S.A.C., 83 U.S.P.Q.2d (BNA) 1320, 2007 WL 549241 (T.T.A.B. 2007); Corp. Cimex S.A. v. D.M. Enters. \& Distribs. Inc., 2008 WL 5078739 (T.T.A.B. 2008) (not precedential); Franpovi S.A. v. Wessin, 89 U.S.P.Q.2d (BNA) 1637, 2009 WL 353299 (T.T.A.B. 2009); Lacteos De Honduras S.A. v. Industrias Sula, S. De R.L. de C.V., 2020 U.S.P.Q.2d 10087, 2020 BL 77266 (T.T.A.B. 2020).

329 Diaz v. Bautista, 2012 U.S. Dist. LEXIS 199199 (C.D. Cal. 2012).

330 Industria De Alimentos Zenú S.A.S. v. Latinfood U.S. Corp., 2017 U.S. Dist. LEXIS 213338 (D.N.J. 2017). 
for unfair competition?31 Because the answer was still then unclear.

Based on his path-breaking trademark practice, Edward Rogers had a keen sense of what protections major U.S. trademark holders desired both when negotiating the Inter-American Convention and when drafting the Lanham Act. These insights were coupled with a sophisticated understanding of the then existing limitations of U.S. and international trademark law. Roger's direct participation in the drafting of the the Inter-American Convention afforded him a perfect understanding of how the rights established in it would have extended protection beyond then existing U.S. trademark law. It may then be regarded as a mystery as to why the 1946 text of the Lanham Act contained such cryptic and inscrutable treatment of unfair competition, when it might have instead been explicit and comprehensive.

The absence of provisions on unfair competition similar to those in the Inter-American Convention in the Lanham Act is less of a mystery considering Rogers's direct and undeniable success in making the convention directly operable in federal court as a selfexecuting treaty. Rogers likely adopted his circuitous approach to incorporation of the convention's protections against unfair competition strategically given the fraught state of federal common law at that time and the resistance to changing that situation legislatively.

This legal history reveals how unfair competition protections were intended to operate in U.S. law by the drafters of the Lanham Act-by codifying rights in a self-executing treaty and incorporating the treaty by reference into the Lanham Act. This ambitious approach by Rogers, however, proved too circuitous for courts applying the new act. Today Rogers's life's work remains obscured.

Trademark practitioners and scholars readily accept that Section 43(a) states a federal claim of unfair competition. This article suggests that federal unfair competition protection in the Lanham Act, however, does not end there. In addition to claims related to consumer confusion of source indicators and false advertising, Section 44(h) and the Inter-American Convention offer additional protections further afield from trademark rights. For

331 The court explicitly asked the parties that basic question during oral argument. Oral Argument, Belmora, LLC v. Bayer Consumer Care AG, 819 F.3d 697 (4th Cir. 2016) (No. 15-1335), https://www.ca4.uscourts.gov/OAarchive/mp3/15-1335-20151027.mp3. The district court centered on this question: "Does the Lanham Act allow the owner of a foreign mark that is not registered in the United States and further has never used the mark in United States commerce to assert priority rights over a mark that is registered in the United States by another party and used in United States commerce?" Belmora LLC v. Bayer Consumer Care AG, 84 F. Supp. 3d 490, 495-96 (E.D. Va. 2015), vacated \& remanded, 819 F.3d 697 (4th Cir. 2016), cert. denied, 137 S. Ct. 1202 (2017) (mem.). 
lack of understanding, however, these protections have thus far lay dormant. 